\title{
RF Sputter-Deposited Nanostructured CuO Films for Micro-Supercapacitors
}

\author{
Goddati Mahendra ${ }^{1}$, Reddappagari Malathi ${ }^{1}$, Sairam P. Kedhareswara ${ }^{1}\left(\mathbb{D}\right.$, Ambadi Lakshmi-Narayana ${ }^{1}$, \\ Merum Dhananjaya ${ }^{1}$, Nunna Guruprakash ${ }^{1}$, Obili M. Hussain ${ }^{1, *}$, Alain Mauger ${ }^{2}$ and Christian M. Julien ${ }^{2, *} \mathbb{D}$ \\ 1 Thin Films Laboratory, Department of Physics, Sri Venkateswara University, Tirupati 517502, India; \\ gmahi066@gmail.com (G.M.); malathi.shuttle@gmail.com (R.M.); \\ kedhareswaranpasupuleti@gmail.com (S.P.K.); Inarayan37@gmail.com (A.L.-N.); \\ msdhananjaya51@gmail.com (M.D.); guruprakash.svu@gmail.com (N.G.) \\ 2 Institut de Minéralogie, de Physique des Matériaux et Cosmologie (IMPMC), Sorbonne Université, \\ CNRS-UMR 7590, 4 Place Jussieu, 75252 Paris, France; alain.mauger@sorbonne-universite.fr \\ * Correspondence: hussainsvu@gmail.com (O.M.H.); christian.julien@sorbonne-universite.fr (C.M.J.)
}

Citation: Mahendra, G.; Malathi, R.; Kedhareswara, S.P.; LakshmiNarayana, A.; Dhananjaya, M.; Guruprakash, N.; Hussain, O.M.; Mauger, A.; Julien, C.M. RF Sputter-Deposited Nanostructured $\mathrm{CuO}$ Films for Micro-Supercapacitors. Appl. Nano 2021, 2, 46-66. https:// doi.org/10.3390/applnano2010005

Received: 20 January 2021

Accepted: 19 February 2021

Published: 25 February 2021

Publisher's Note: MDPI stays neutral with regard to jurisdictional claims in published maps and institutional affiliations.

Copyright: (c) 2021 by the authors. Licensee MDPI, Basel, Switzerland. This article is an open access article distributed under the terms and conditions of the Creative Commons Attribution (CC BY) license (https:/ / creativecommons.org/licenses/by/ $4.0 /)$.

\begin{abstract}
Copper oxide is considered as an alternative electrode material for supercapacitors due to its low cost, chemical stability and high theoretical specific capacitance. In the present work, nanostructured copper oxide $(\mathrm{CuO})$ films are prepared by radio-frequency $(\mathrm{RF})$ magnetron sputtering, and the influence of the substrate temperature on the microstructure and supercapacitive properties was studied. The copper oxide films prepared at $350{ }^{\circ} \mathrm{C}$ exhibit a predominant $(\overline{1} 11)$ orientation corresponding to the monoclinic $\mathrm{Cu}(\mathrm{II}) \mathrm{O}$ phase with a crystallite size of $24 \mathrm{~nm}$. The surface of the film consists of uniformly distributed oval-like grains providing a high surface roughness of $45 \mathrm{~nm}$. The films exhibit an optical bandgap of $1.68 \pm 0.01 \mathrm{eV}$ and an electrical conductivity of $0.4 \mathrm{~S} \mathrm{~cm}^{-1}$ at room temperature. The as-prepared $\mathrm{CuO}$ films deliver a discharge specific capacitance of $387 \mathrm{mF} \mathrm{cm}^{-2}$ (375 F g $\mathrm{g}^{-1}$ ) at a current density of $1 \mathrm{~mA} \mathrm{~cm}^{-2}$ with excellent cyclic capacitance retention of $95 \%\left(367 \mathrm{mF} \mathrm{cm}^{-2}\right)$ even after 1000 cycles. Hence, these films are potential electrodes for micro-supercapacitors.
\end{abstract}

Keywords: copper oxide; films; RF magnetron sputtering; nanostructure; supercapacitor; energy storage

\section{Introduction}

The spectacular development of the microelectronic industry is day-by-day downscaling its products for a wide range of applications such as medical implants, micro-sensors, self-powered integrated circuits or micro-electro-mechanical systems (MEMS). The reduction in size and improvement in the capability of such microsystems demand a high-energy and high-power unit in a small footprint area with dimensions at the scale of $1-10 \mathrm{~mm}^{2}$, including all the components and the associated packing. However, the fabrication of micro-miniaturized energy storage and conversion devices and the respective interconnects is still challenging [1-3]. In the present scenario, intensive investigations are in progress for the development of two complementary electrochemical energy storage devices, viz., Li-ion microbatteries and micro-supercapacitors. The micro-supercapacitors based on capacitive ion adsorption/desorption in electrodes, which offer an optimum cycle life (>100,000 cycles), are particularly attractive for high-power applications (>10 mW $\mathrm{cm}^{-2}$ ) [4-7]. The efficiency of micro-supercapacitors is mainly dependent on suitable electrode materials that facilitate the ion motion between the electrode surface and electrolyte to generate high capacitance and store energy through faradaic redox reactions. Due to their high oxidation states, transition metal oxides (TMOs) demonstrate efficient redox charge storage, meaning that they could satisfy the needs of high energy density and power density [8,9]. Among various electrode materials, $\mathrm{CuO}$ has been extensively investigated as a supercapacitive material due to its low cost, abundant resources, high chemical stability, 
high theoretical capacity $\left(690 \mathrm{~F} \mathrm{~g}^{-1}\right)$ and non-toxic nature [10-12]. Copper oxide was one of the first semiconducting materials studied in the 1930s [13,14]. It has two major forms: (i) copper(II) oxide (CuO, tenorite), a defect p-type semiconductor, which crystallizes in the monoclinic structure $(\mathrm{C} 2 / c$ space group, $\# 15)$ with high absorbability, low thermal emittance and a moderate bandgap of 1.1-1.7 eV [15]; and (ii) copper(I) oxide $\left(\mathrm{Cu}_{2} \mathrm{O}\right.$, cuprite), which crystallizes in the cubic structure (Pnm space group, \#224) and exhibits a wider bandgap of 1.8-2.5 eV [16].

Due to their merits and easy fabrication, $\mathrm{CuO}$ films are extensively used in versatile applications such as microelectronic devices [17], sensors [18] and solar energy conversion [19]. The microstructural and surface morphological properties of $\mathrm{CuO}$ films are determined by their preparation technique. $\mathrm{CuO}$ films have been grown using various deposition techniques such as thermal oxidation [20], electrodeposition [21,22], pulsed-laser deposition [23], plasma evaporation [24], thermal evaporation [25], reactive sputtering [26], electron-beam evaporation [27], molecular-beam epitaxy [28], spray pyrolysis [29,30], spin coating [31], successive ionic layer adsorption and reaction (SILAR) [32] and chemical vapor deposition [33,34]. Among these film deposition processes, radio-frequency (RF) magnetron sputtering is one of the most pre-eminent industrial practical techniques to achieve high-quality and uniform thickness films with the required chemical composition [35]. For two decades, RF magnetron sputtering has become the most popular deposition technique for the growth of crystalline $\mathrm{CuO}$ films [36-45]. Further, during deposition, thermally activated parameters such as the relaxation time to dissipate the kinetic energy of sputtered species, surface diffusion and structural changes in the surface are effectively influenced by the oxygen partial pressure and the substrate temperature. A previous work showed that changes in the phase of copper oxide films from metallic copper to $\mathrm{Cu}_{2} \mathrm{O}$ and $\mathrm{Cu}_{2} \mathrm{O}$ to $\mathrm{Cu}_{4} \mathrm{O}_{3}$ and then to $\mathrm{CuO}$ were observed by varying the ratio of the $\mathrm{O}_{2} / \mathrm{Ar}$ gas mixture from 1:25 to 1:1 [42]. The reported capacitance for the films was $357 \mathrm{~F} \mathrm{~g}^{-1}$ at a low current density of $0.5 \mathrm{~mA} \mathrm{~cm}^{-2}$.

The suitability and electrochemical performance of the film electrode to be used in micro-supercapacitors should satisfy the following criteria:

(a) Stable crystallographic structure with good integrity between the crystallites to avoid running-off of the active material during the electrochemical intercalation and deintercalation process for long cycle stability.

(b) The microstructure of the electrode with a high specific surface area and high mesoporosity provides more intercalation sites for enhancement of the specific capacitance.

(c) Reasonable conductivity of the electrode yields low charge transfer resistance and, in turn, improves the transportation of electrons and ions.

(d) Good adhesion among the layers avoids the running-off of the material.

The electrochemical performance mainly depends upon the microstructure, surface morphology and electrical properties of the films which, in turn, depend upon the type of deposition technique and process parameters employed during the film growth. Extensive investigations have been conducted on the growth of $\mathrm{CuO}$ films using RF magnetron sputtering by varying all deposition parameters, i.e., $T_{\mathrm{s}}, \mathrm{Ar} / \mathrm{O}_{2}$ ratio and $\mathrm{RF}$ power, which is a single-step process. The optimized deposition conditions of the $\mathrm{O}_{2}$-to-Ar gas flow ratio at 1:7 and RF power at $250 \mathrm{~W}$ determined in earlier work [42] are kept constant and the temperature of the $\mathrm{Si}$ substrate is varied to obtain high supercapacitance performance. Growth of a single-phase $\mathrm{CuO}$ film with a good crystalline nature is very difficult. It was demonstrated that the pure $\mathrm{CuO}$ monoclinic phase is stable in this temperature range, while the film grown at $T_{\mathrm{s}}<250{ }^{\circ} \mathrm{C}$ is amorphous in nature or poorly crystallized and displays a mixture of cubic $\mathrm{CuO}$ and $\mathrm{Cu}_{2} \mathrm{O}$. At $T_{\mathrm{s}}>450{ }^{\circ} \mathrm{C}$, impurity phases such as $\mathrm{Cu}_{2} \mathrm{O}$ and $\mathrm{Cu}_{4} \mathrm{O}_{3}$ are mixed with monoclinic $\mathrm{CuO}[20,33,41]$. Hence, we have focused our attention more critically to observe the crystalline growth between 300 and $400{ }^{\circ} \mathrm{C}$ with a step of $25^{\circ} \mathrm{C}$. This work emphasizes the optimization of the deposition temperature in relation to the film microstructure and morphology. A detailed study was conducted to arrive at an optimum deposition temperature of $350^{\circ} \mathrm{C}$, where the $\mathrm{CuO}$ films demonstrate 
a single phase with a monoclinic structure, better crystallinity, high surface area and reasonable electronic conductivity. These binder-free films were employed in the fabrication of an electrochemical cell and demonstrated pseudo-capacitance behavior with high specific capacitance and a long cycle life.

Note that the number of works reporting the supercapacitive properties of $\mathrm{CuO}$ films is very limited. We only identified nine articles, which are listed in Table 1 with the brief description of the synthesis procedures [31,43-50]. All works show multi-step processes (at least three steps) used for the synthesis of $\mathrm{CuO}$ films, which are rather complex and costly methods compared with the one-step magnetron sputtering technique, which is also scalable for low-cost industrial production without the use of chemicals in aqueous solutions. Moreover, the $\mathrm{CuO}$-based micro-supercapacitors can be fabricated in a unique vacuum chamber by successive depositions of the device elements, i.e., current collectors, solid electrolyte and counter electrode, using the same process.

Table 1. Description of the stepped synthesis of $\mathrm{CuO}$ films for supercapacitors.

\begin{tabular}{lll}
\hline Number of Steps & Successive Processes & Ref. \\
\hline 3 & Solution + SILAR (90 cycles) + annealing & {$[31]$} \\
4 & Solution + refluxing + washing + drying & {$[43]$} \\
3 & Solution + spray pyrolysis + annealing & {$[44]$} \\
3 & Ultrasonication + spray pyrolysis + drying & {$[45]$} \\
3 & Solution + chemical bath (pH control) + drying & {$[46]$} \\
3 & Solution + precipitation process + annealing & {$[47]$} \\
3 & Solution + chemical bath + annealing & {$[48]$} \\
5 & Solution + filtration + washing + drying + annealing & {$[49]$} \\
4 & Acid treatment + surface oxidation + washing + drying & {$[50]$} \\
\hline
\end{tabular}

\section{Materials and Methods}

\subsection{CuO Film Deposition}

Films of copper monoxide $(\mathrm{CuO})$ were deposited on silicon substrates by the RF magnetron sputtering technique using a 3" circular copper metal target of $99.99 \%$ purity. The chamber (24" Box Coater-Hind High Vacuum) was evacuated to a base pressure of $5.4 \mathrm{mPa}$ using a turbo-molecular pump backed by a rotary pump. The Cu metal target (purity 99.99\%) was pre-sputtered for $10 \mathrm{~min}$ by introducing Ar gas into the chamber to remove the native oxide layer from the target. Throughout the deposition procedure, the RF power and ratio of the $\mathrm{O}_{2} / \mathrm{Ar}$ gas mixture were maintained at $250 \mathrm{~W}$ and 1:7, respectively [42,51]. The source to substrate distance was kept constant at $8.0 \mathrm{~cm}$ and the sputtering pressure was maintained at $2 \mathrm{~Pa}$ during the deposition. Samples were elaborated at different substrate temperatures between 300 and $400{ }^{\circ} \mathrm{C}$ with a step of $25^{\circ} \mathrm{C}$. The experimental diagram of the RF magnetron sputtering process to prepare $\mathrm{CuO}$ films is shown in Scheme 1.

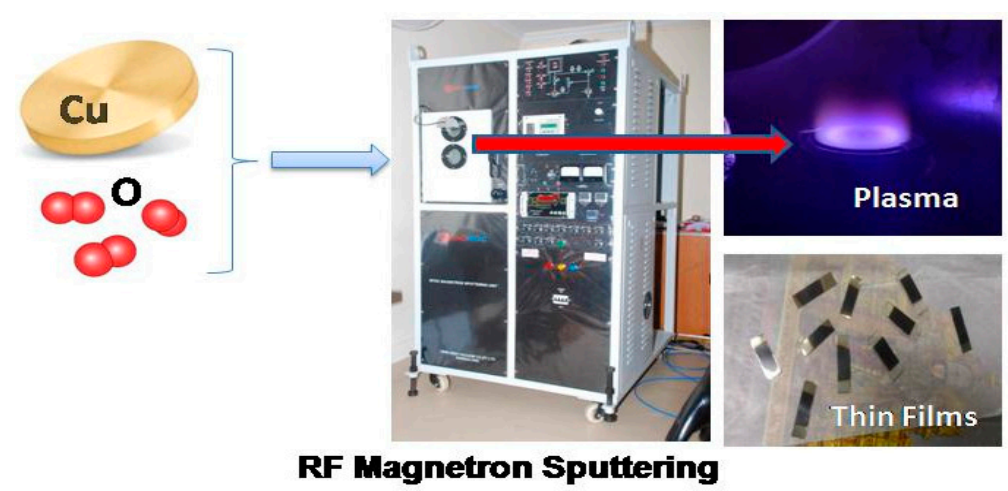

Scheme 1. Illustration of the experimental radio-frequency (RF) magnetron sputtering technique used for the preparation of $\mathrm{CuO}$ thin films. Working plasma and final products are also pictured. 


\subsection{Characterization}

The phase identification of the as-grown $\mathrm{CuO}$ films was carried out by $\mathrm{X}$-ray diffraction (XRD, Seifert X-ray diffractometer, model 3003TT) equipped with a $\mathrm{CuK}_{\alpha 1}$ radiation source $(\lambda=0.15406 \mathrm{~nm})$ in the $2 \theta$ range from $10^{\circ}$ to $100^{\circ}$, at a scan rate of $0.03^{\circ} \mathrm{s}^{-1}$. The structural analysis of $\mathrm{Cu}$ oxide was also performed by Raman spectroscopy using a LabRAM-HR 800 confocal apparatus (Horiba, Kyoto, Japan) with the He-Ne laser line at $632 \mathrm{~nm}$ as the excitation wavelength. The surface morphological properties were studied using atomic force microscopy (AFM, model SOLVER Next, NT-MDT Spectrum Instruments, New Delhi, India) and scanning electron microscopy (SEM, model Carl Zeiss EVO50, Jena, Germany). The surface roughness and grain size were characterized using Nova PX software. The thickness of the prepared film was measured using a stylus-type surface profiler (Mitutoyo Surftest SJ-301, Kanagawa, Japan). The elemental composition and surface analyses were conducted by X-ray photoelectron spectroscopy (XPS, model PHI Versa Probe II, Physical electronics Inc., Chanhassen, MN, USA) equipped with a rotating anode ( $\mathrm{Al} \mathrm{K} \alpha$, radiation source, $\lambda=1486.6 \mathrm{eV}$ ). The binding energy (BE) values were referenced to the $\mathrm{C} 1 \mathrm{~s}$ core level at $284.5 \mathrm{eV}$. The optical transmittances of as-prepared films were recorded by a UV-VIS-NIR double-beam spectrometer (model Lambda 950, Perkin Elmer, Rodgau, Germany) in the wavelength range from 300 to $1100 \mathrm{~nm}$. The electrical properties were studied using the standard four-probe technique. The electrochemical properties such as cyclic voltammetry $(\mathrm{CV})$ and galvanostatic charge-discharge (GCD) and electrochemical impedance spectroscopy (EIS) measurements were carried out using a three-electrode aqueous cell. The as-prepared $\mathrm{CuO}$ films deposited on silicon substrates, platinum strip and $\mathrm{Ag} / \mathrm{AgCl}$ electrodes were used as working, counter and reference electrodes, by which the electrochemical analysis was calibrated in the presence of a phosphate-buffered aqueous solution (PBS, Life Technologies, Carlsbad, CA, USA) of $\mathrm{pH}$ 7.2 as the electrolyte. The electrochemical tests were performed using an electrochemical analyzer, the $\mathrm{CHI} 608 \mathrm{C}$ instrument. All the experiments were conducted at $25^{\circ} \mathrm{C}$.

\section{Results}

\subsection{Structure and Morphology}

The structural properties of the RF sputtered $\mathrm{CuO}$ films were investigated by XRD and Raman spectroscopy, while the film morphology was examined by SEM and AFM experiments. The as-prepared $\mathrm{CuO}$ films deposited at $300 \leq T_{\mathrm{s}} \leq 400{ }^{\circ} \mathrm{C}$ without subsequent annealing have a uniform aspect without pinholes, distinct bump formation and a surface with the appearance of granular morphology. The thicknesses of as-grown films are in the range 1.37-1.53 $\mu \mathrm{m}$.

Figure 1 presents the XRD diffractograms in the range $10 \leq 2 \theta \leq 100^{\circ}$ of RF sputtered $\mathrm{CuO}$ films prepared at five different substrate temperatures of $300,325,350,375$ and $400{ }^{\circ} \mathrm{C}$. The XRD pattern of the $\mathrm{CuO}$ film prepared at $350^{\circ} \mathrm{C}$ exhibits the predominant reflection at the $2 \theta$ angle of $35.37^{\circ}$ with $d_{\mathrm{hkl}}$ of $0.253 \mathrm{~nm}$ ascribed to the $(\overline{1} 11) /(002)$ planes. Diffraction peaks of lower intensity at $32.61^{\circ}, 38.75^{\circ}, 62.05^{\circ}, 76.17^{\circ}$ and $89.71^{\circ}$ are attributed to the reflection planes (110), (111)/(200), (113), (222) and (131) with $d_{\mathrm{hkl}}$ of $0.278,0.236,0.149$, 0.117 and $0.109 \mathrm{~nm}$, respectively. All diffraction peaks match well with the standard data (JCPDS card no. 89-2531) and reveal the growth of single-phase $\mathrm{CuO}$ with the tenorite-type monoclinic structure. It can be observed that the intensity of all diffraction peaks reaches a maximum at $T_{\mathrm{s}}=350{ }^{\circ} \mathrm{C}$, which indicates that it is the optimized temperature where the superior crystallinity is reached. No extra peak is observed (see Figure 1), which provides evidence that the film is free of any impurities and other $\mathrm{Cu}$-based phases, i.e., $\mathrm{Cu}_{2} \mathrm{O}, \mathrm{Cu}_{3} \mathrm{O}_{4}$ or $\mathrm{Cu}(\mathrm{OH})_{2}$. Moreover, the polycrystalline monoclinic lattice is confirmed, in contrast with the cubic structure observed for films deposited at $T_{\mathrm{s}}<300{ }^{\circ} \mathrm{C}$. These results are consistent with data reported in the literature [52-55]. In the substrate temperature range $300 \leq T_{\mathrm{s}} \leq 400{ }^{\circ} \mathrm{C}$, the films exhibit preferential growth of the grains along the (111) orientation. 


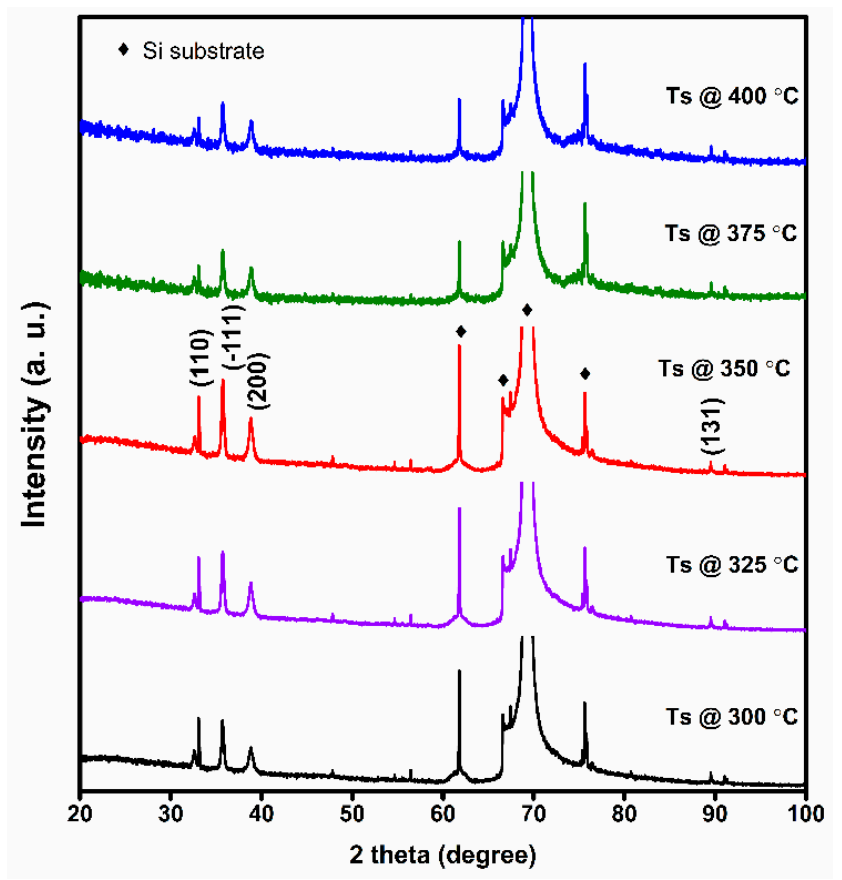

Figure 1. XRD spectra of $\mathrm{CuO}$ films deposited on silicon substrates maintained at different temperatures in the range $300-400{ }^{\circ} \mathrm{C}$. The asterisks denote the XRD reflections of the Si substrate.

The lattice parameters of the $\mathrm{CuO}$ films were determined using a least-squares fitting method with six reflection lines (monoclinic structure, $C 2 / c$ space group). The obtained values are $a=4.674(2) \AA, b=3.471(8) \AA, c=5.117(0) \AA$ and $\beta=98.61$ for the films grown at $350{ }^{\circ} \mathrm{C}$ and an elementary unit volume $V=a b c \sin \beta$ of $83.015 \AA^{3}$. The elementary unit volume is only $0.2 \%$ less than the value for the bulk crystal, indicating the formation of rather dense films [56]. The crystallite (grain) size $(L)$ of the RF sputtered $\mathrm{CuO}$ films was calculated using the Debye-Scherrer's formula [57]:

$$
L=\frac{K \lambda}{B \cos \theta}
$$

where $K$ is a dimensionless shape factor ( 0.9 for quasi-spherical particles), $\lambda$ is the wavelength of the X-ray source, $B$ is the full width at half maximum (FWHM) and $\theta$ is the Bragg angle. The dislocation density ( $\delta$ ), indicating the density of defects in the films, and the micro-strain $(\varepsilon)$ were calculated using the following equations:

$$
\begin{gathered}
\delta=\frac{1}{L^{2}}, \\
\varepsilon=\frac{B}{4 \tan \theta} .
\end{gathered}
$$

Results of the crystallographic parameters are summarized in Table 2. The estimated crystallite sizes $( \pm 1 \mathrm{~nm})$ of the $\mathrm{CuO}$ films deposited at $T_{\mathrm{s}}$ of 300,350 and $400{ }^{\circ} \mathrm{C}$ are found to be 18,24 and $22 \mathrm{~nm}$, respectively. It can be observed that the crystallite size increases initially (from 18 to $24 \mathrm{~nm}$ ) upon increasing $T_{\mathrm{s}}$ in the range $300-350{ }^{\circ} \mathrm{C}$, and then it is unchanged $(\sim 24 \mathrm{~nm})$ with a further increase of $T_{\mathrm{S}}$ from 350 to $400{ }^{\circ} \mathrm{C}$. The small crystallite size at $300{ }^{\circ} \mathrm{C}$ is attributed to the large number of grain boundaries, which creates a free volume in films and produces a hydrostatic-like pressure responsible for high stress and high dislocation densities [58]. For the further increase in $T_{\mathrm{s}}$ from 300 to $350{ }^{\circ} \mathrm{C}$, the crystallite size increases by $30 \%$ because less free volume occurs at high $T_{\mathrm{s}}$, which causes lower stress in the film. More precisely, from the substrate side, the potential barrier should become flat and the diffusion of ad-atoms should occur. In addition, a large number of ad-atoms are originated and may coalesce, improving the crystallite size [36]. On the 
other hand, at $T_{\mathrm{S}}=400{ }^{\circ} \mathrm{C}$, the crystallite size is reduced by $8 \%$. This has been attributed to the creation of oxygen vacancies [59], responsible for local distortions, and thus an increase in the strain field [36]. As a result, a lower crystallinity is observed. The results in Table 2 show that the optimized $T_{\mathrm{s}}=350{ }^{\circ} \mathrm{C}$ of the deposit is the temperature leading not only to the best crystallinity, but also to the minimum of the strain field inside the film.

Table 2. The crystallographic parameters for as-grown monoclinic $\mathrm{CuO}$ films (i.e., lattice parameters, grain size, lattice strain and dislocation density). Errors in lattice parameters are $\pm 0.0001 \AA$.

\begin{tabular}{|c|c|c|c|c|c|c|c|}
\hline \multirow{2}{*}{$T_{\mathrm{s}}\left({ }^{\circ} \mathrm{C}\right)$} & \multicolumn{4}{|c|}{ Lattice Parameters } & \multirow{2}{*}{$\begin{array}{l}\text { Grain } \\
\text { Size } \\
(\mathrm{nm})\end{array}$} & \multirow{2}{*}{$\begin{array}{c}\begin{array}{c}\text { Strain } \\
<\mathrm{e}> \\
\times 10^{-3}\end{array} \\
\end{array}$} & \multirow{2}{*}{$\begin{array}{c}\text { Dislocation } \\
\text { Density } \\
10^{17} \mathrm{~cm}^{-2}\end{array}$} \\
\hline & a $(\AA)$ & b (̊) & c ( $(\AA)$ & $\beta\left({ }^{\circ}\right)$ & & & \\
\hline 300 & $4.664(2)$ & $3.466(1)$ & $5.111(5)$ & $98.70(1)$ & 18 & 4.12 & 3.1 \\
\hline 325 & $4.669(9)$ & $3.467(5)$ & $5.114(3)$ & $98.65(2)$ & 20 & 3.88 & 2.5 \\
\hline 350 & $4.674(2)$ & $3.471(8)$ & $5.117(0)$ & $98.61(0)$ & 24 & 3.32 & 1.7 \\
\hline 375 & 4.677(7) & $3.472(2)$ & $5.121(3)$ & $98.64(5)$ & 22 & 3.64 & 2.0 \\
\hline 400 & $4.689(3)$ & $3.478(1)$ & $5.127(1)$ & $98.66(3)$ & 22 & 3.97 & 2.1 \\
\hline
\end{tabular}

The phase identification was also performed by Raman spectroscopy. Figure 2 shows the spectrum of the sputtered $\mathrm{Cu}-\mathrm{O}$ film deposited on the Si substrate and heated at $350{ }^{\circ} \mathrm{C}$ with a power of $250 \mathrm{~W}$ in the $\mathrm{O}_{2} / \mathrm{Ar}(1: 7)$ gas mixture. The Raman spectrum shows three bands located at 298, 330 and $602 \mathrm{~cm}^{-1}$, which are the characteristic vibrations of the monoclinic $\mathrm{CuO}$ crystal. They are assigned to the $\mathrm{A}_{\mathrm{g}}, \mathrm{B}_{\mathrm{g}}{ }^{(1)}$ and $\mathrm{B}_{\mathrm{g}}{ }^{(2)}$ Raman active modes, respectively, with the peak at $602 \mathrm{~cm}^{-1}$ being a $\mathrm{Cu}-\mathrm{O}$ stretching mode [60]. The strong peak at $520 \mathrm{~cm}^{-1}$ is the first-order Raman active mode of the Si substrate. The presence of both phases of $\mathrm{Cu}_{2} \mathrm{O}$ and $\mathrm{Cu}_{4} \mathrm{O}_{3}$ is excluded since the Raman peaks at $218\left(\mathrm{Cu}_{2} \mathrm{O}\right)$ and $533 \mathrm{~cm}^{-1}\left(\mathrm{Cu}_{4} \mathrm{O}_{3}\right)$ are not observed. Thus, from Raman and XRD analyses, the monoclinic $\mathrm{CuO}$ phase is clearly identified. Note that Raman spectroscopy is a very sensitive tool to detect such impurities and more sensitive than XRD in particular. The Raman spectra are thus a probe of the purity of the $\mathrm{CuO}$ film.

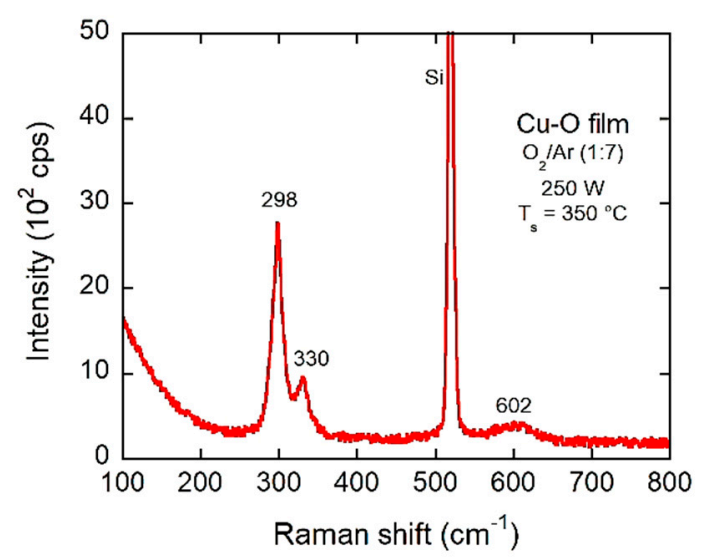

Figure 2. Raman spectrum of the sputtered $\mathrm{Cu}-\mathrm{O}$ film deposited on $\mathrm{Si}$ substrate and heated at $350{ }^{\circ} \mathrm{C}$ with a power of $250 \mathrm{~W}$ in the $\mathrm{O}_{2} / \mathrm{Ar}(1: 7)$ gas mixture.

The surface morphology of the $\mathrm{CuO}$ films deposited on the silicon wafer was investigated by SEM. Figure 3 shows the 2D SEM images $(a-c)$ and 3D SEM images $(d-f)$ obtained by using NOVA Px software. The 2D images display a regular surface coverage that is crack-free with high densities in contact with the silicon substrate. Further, the micrographs reveal a very homogeneous grain size distribution (i.e., almost monodisperse). The grain size (100-200 nm) bigger than that of crystallites indicates the polycrystalline form of the as-sputtered films. At $T_{\mathrm{S}}<300{ }^{\circ} \mathrm{C}$, the films exhibit aggregation of grains, which indicates that the crystalline structure is initiated at $300{ }^{\circ} \mathrm{C}$. This is thus the threshold temperature at which the sputtered $\mathrm{CuO}$ species receive the potential energy of nucleation sites to form 
the crystalline film. When the substrate temperature increases from 300 to $350{ }^{\circ} \mathrm{C}$, we observe well-ordered grains and grain boundaries, with corresponding development in the grain size and surface roughness. The surface topography of the $\mathrm{CuO}$ films deposited at $T_{\mathrm{s}}=350^{\circ} \mathrm{C}$ displays a uniform distribution of grains. A detailed examination of SEM images in Figure 3 reveals the same tendency of the increasing grain size to that of the crystallite size. The grain size is increased with increasing the substrate temperature from 300 to $350{ }^{\circ} \mathrm{C}$. The average grain size of the prepared sample at the substrate temperature of $350{ }^{\circ} \mathrm{C}$ is $140 \mathrm{~nm}$. For the further increase in $T_{\mathrm{s}}$ from 350 to $400{ }^{\circ} \mathrm{C}$, the grain size is decreased. Thus, according to the XRD and SEM results, we consider that the best $\mathrm{CuO}$ film suitable for further characterizations was obtained at $T_{\mathrm{s}}=350^{\circ} \mathrm{C}$.
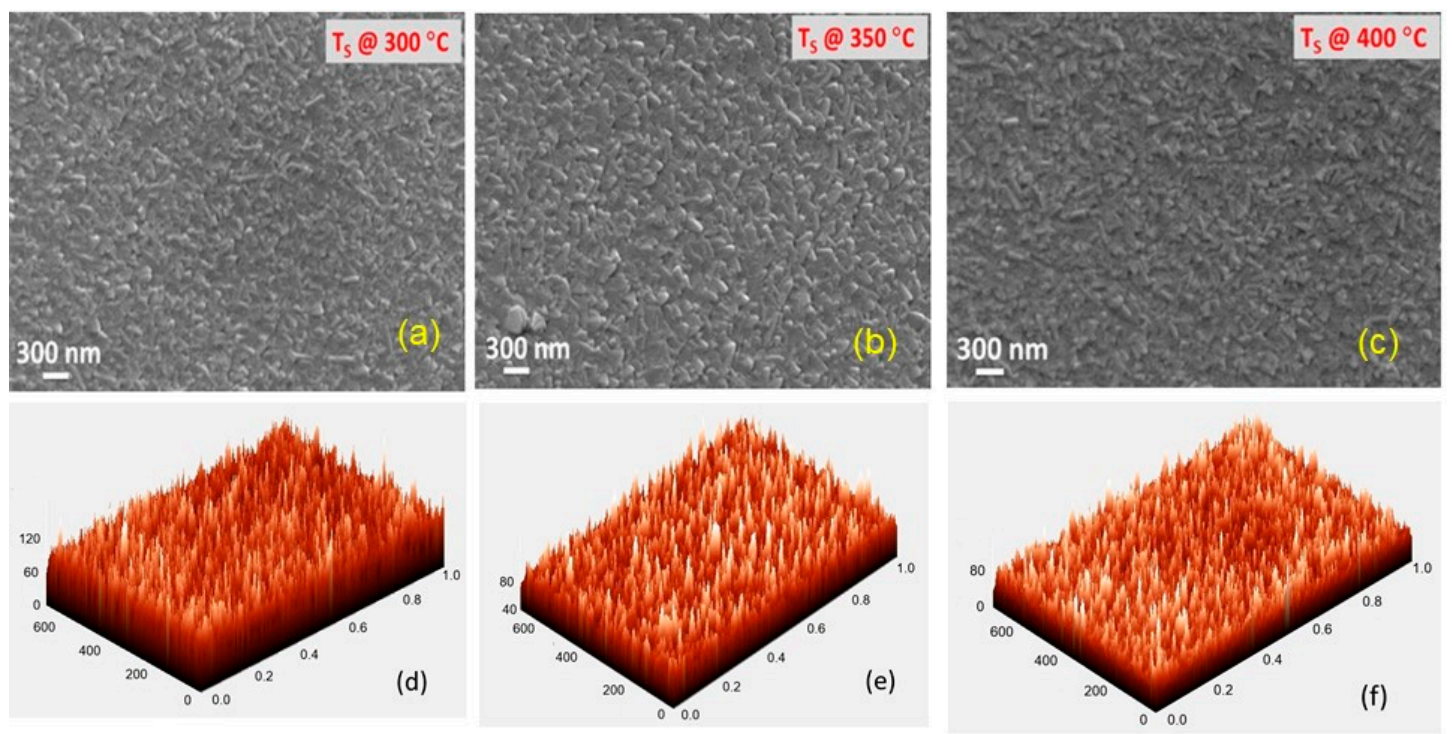

Figure 3. (a-c) 2D SEM images of RF magnetron sputtered $\mathrm{CuO}$ films grown on Si substrates maintained at different temperatures $\left(300 \leq T_{\mathrm{s}} \leq 400{ }^{\circ} \mathrm{C}\right)$. $(\mathbf{d}-\mathbf{f}) 3 \mathrm{D}$ images obtained by NOVA Px software.

The surface topography of $\mathrm{CuO}$ films was studied by AFM measurements. Figure 4 presents the $2 \mathrm{D}$ and $3 \mathrm{D}$ topographical images showing the grain distribution and surface roughness of the RF sputtered $\mathrm{CuO}$ films at $T_{\mathrm{s}}=350{ }^{\circ} \mathrm{C}$. The $2 \mathrm{D} 800 \times 800 \mathrm{~nm}^{2}$ image displays a compact and granular morphology of the film (Figure 4a). It can be seen that the surface of the film consists of elongated grains uniformly distributed with a high surface-tovolume ratio. The 3D AFM micrograph (Figure $4 \mathrm{~b}$ ) shows profound grain features and less voided boundaries, revealing the formation of densely packed grains. Using the Nova PX software, the calculated average grain size and surface roughness of the films are $134 \pm 2$ and $45 \pm 2 \mathrm{~nm}$, respectively. This topology confirms the results from SEM and XRD studies. Note that the root mean square surface roughness for $\mathrm{Si}$ substrates is $\sim 3 \mathrm{~nm}$. Thus, the morphology of $\mathrm{CuO}$ films cannot be influenced by the $\mathrm{Si}$ substrate, which has a small grain-like structure.

In particular, the $\mathrm{CuO}$ film deposited at $350^{\circ} \mathrm{C}$ with a large grain size $(143 \mathrm{~nm})$ shows a high value of the root mean square $(\mathrm{rms})$ roughness of $45 \mathrm{~nm}$. This may be due to the fact that larger particles with an oval-elongated morphology exhibit higher differences in the height ( $\mathrm{z}$ range) by the side of their boundaries in comparison to the smaller grain. The Brunauer-Emmett-Teller (BET) specific surface area $S_{B E T}$ can be calculated by the relation [61]:

$$
S_{B E T}=\frac{K \lambda}{\rho D},
$$

where $\lambda$ is the surface roughness, $\rho$ is the grain density, $D$ is the average grain diameter and $K$ is a geometry factor ( $K$ equals 6 for ideal spheres). Using a density of $\rho \approx 6 \mathrm{~g} \mathrm{~cm}^{-3}$ 
for the well-crystallized $\mathrm{CuO}$ film deposited at $350{ }^{\circ} \mathrm{C}$, one obtains $S_{B E T}=10.5 \mathrm{~m}^{2} \mathrm{~g}^{-1}$, which is an important factor for the electrochemical performance of the SC electrode.
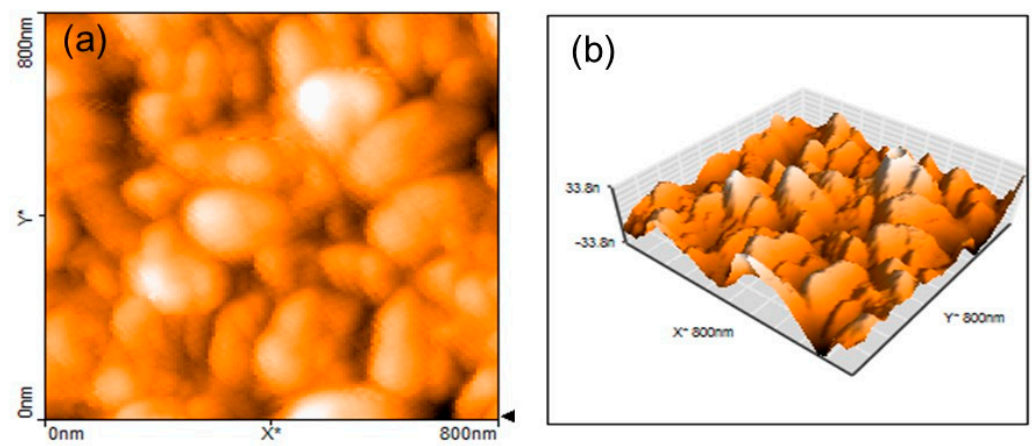

Figure 4. Topology of RF sputtered $\mathrm{CuO}$ films prepared at $\mathrm{T}_{\mathrm{S}}$ of $350^{\circ} \mathrm{C}$ on $\mathrm{Si}$ substrate. (a) $2 \mathrm{D}$ and (b) 3D AFM images.

\subsection{XPS Studies}

The chemical states of RF sputtered $\mathrm{CuO}$ films prepared on the $\mathrm{Si}$ substrate and heated at a $T_{\mathrm{S}}$ of $350{ }^{\circ} \mathrm{C}$ were investigated by XPS, as shown in Figure 5 . The characteristic core level spectrum of $\mathrm{Cu} 2 \mathrm{p}$ is recorded in the binding energy range $920-960 \mathrm{eV}$ (Figure 5a), while the broad peak of $\mathrm{O} 1 \mathrm{~s}$ is pointed out at $529.7 \mathrm{eV}$ (Figure $5 \mathrm{~b}$ ). The $\mathrm{Cu} 2 \mathrm{p}$ spectrum displays the two peaks located at 952.0 and $933.2 \mathrm{eV}$ corresponding to the binding energies of $\mathrm{Cu} 2 \mathrm{p}_{1 / 2}$ and $\mathrm{Cu} 2 \mathrm{p}_{3 / 2}$, respectively, along with the satellite components. The binding energy of the $\mathrm{Cu} 2 \mathrm{p}_{3 / 2}$ peak at $933.2 \mathrm{eV}$ confirms the oxidation state of $\mathrm{Cu}$ (II) of the monoclinic $\mathrm{CuO}$ phase, which differs from the binding energy of $932.4 \mathrm{eV}$ for $\mathrm{Cu}$ (I) [62]. The two observed satellite peaks for $\mathrm{Cu} 2 \mathrm{p}$ are characteristic features of the $\mathrm{CuO}$ phase [63]. Moreover, the splitting between the binding energies of $2 \mathrm{p}_{3 / 2}$ and $2 \mathrm{p}_{1 / 2}$ core levels of $18.8 \mathrm{eV}$ matches well with the standard spectrum of $\mathrm{CuO}$. The single peak of the $\mathrm{O} 1 \mathrm{~s}$ core level located at a binding energy of $529.7 \mathrm{eV}$ provides conclusive evidence of lattice oxygen bound to $\mathrm{Cu}^{2+}$ within the monoclinic $\mathrm{CuO}$ phase. The obtained results are consistent with the reported values in [64].
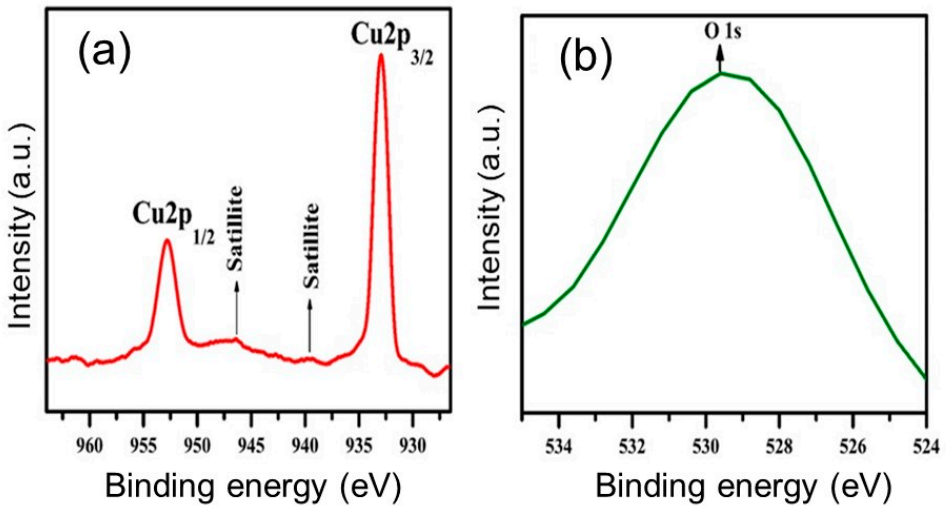

Figure 5. XPS spectra of $\mathrm{CuO}$ films deposited at $T_{\mathrm{s}}$ of $350{ }^{\circ} \mathrm{C}$. (a) $\mathrm{Cu} 2 \mathrm{p}$ spectrum and (b) $\mathrm{O}$ 1 s spectrum.

\subsection{Optical Bandgap}

The optical bandgap of $\mathrm{CuO}$ films was determined using optical spectroscopy in the vicinity of the fundamental transition, i.e., wavelength range of 300-1100 nm. Due to the crystallinity and high transparency of copper oxide, measurements were carried out using films (less than $300 \mathrm{~nm}$ thick) deposited on glass slides. Figure 6a shows the plots of the transmittance and reflectance vs. the incident energy for the films deposited at different substrate temperatures. An optical transmittance of $\sim 65 \%$ is recorded in the 
wavelength range of 850-1100 $\mathrm{nm}$. All samples exhibit strong absorption in the visible and near-infrared region up to $800 \mathrm{~nm}$. The optical absorption coefficient $(\alpha)$ was calculated taking into consideration the transmittance $(\mathrm{T} \%)$ and reflectance $(\mathrm{R} \%)$ of the film using the standard equation [65]:

$$
\alpha=\frac{1}{d} \ln \left[\frac{(1-R)^{2}}{T}\right],
$$

where $d$ is the film thickness. The bandgap $E_{\mathrm{g}}$ of films was calculated by Tauc's formula [66]:

$$
\alpha h v=A\left(E_{\mathrm{g}}-h v\right)^{n},
$$

where $h v$ is the incident photon energy and $A$ is a constant depending on several intrinsic properties of the material, i.e., the effective mass of the electron and hole and the material refractive index. The exponent $n$ depends on the type of optical transition that prevails. It is equal to $\frac{1}{2}, 3 / 2,2$ and 3 for the direct-allowed, direct-forbidden, indirect-allowed and indirect-forbidden transitions, respectively [66]. Note that the knowledge of the bandgap is also useful for the phase identification of the films, such as $1.1 \leq E_{\mathrm{g}} \leq 1.7 \mathrm{eV}$ for $\mathrm{CuO}$, and $1.8 \leq E_{\mathrm{g}} \leq 2.5 \mathrm{eV}$ for $\mathrm{Cu}_{2} \mathrm{O}$. The bandgap of the as-prepared films is calculated by the plot of $(\alpha h v)^{n}$ against $h v$ and the extrapolation of the linear portion to the energy axis $(\alpha=0)$. As copper oxide is a direct-allowed semiconductor, the graph in Figure $6 \mathrm{~b}$ is plotted with $(\alpha h v)^{2}$ vs. $h v$. It can be observed that, with increasing $T_{\mathrm{s}}$ from 300 to $350{ }^{\circ} \mathrm{C}$, the optical energy bandgap values $( \pm 0.01 \mathrm{eV})$ were marginally decreased from 1.72 to $1.68 \mathrm{eV}$ and increased to $1.70 \mathrm{eV}$ with a further increase in the temperature to $400{ }^{\circ} \mathrm{C}$. Indeed, the optical properties of the films critically depend on the physical properties, and these variations in the energy gap here are consistent with those of the crystallite size.
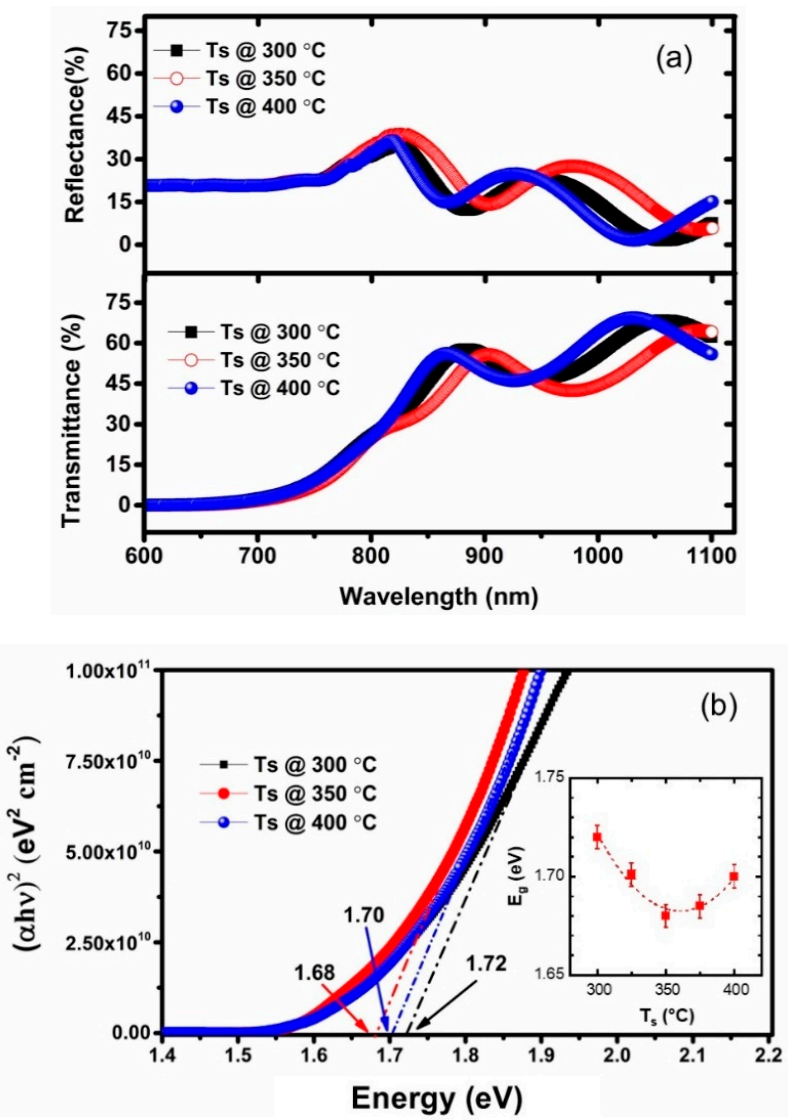

Figure 6. Optical properties of RF sputtered $\mathrm{CuO}$ films prepared at different substrate temperatures in the $\mathrm{O} 2 / \mathrm{Ar}(1: 7)$ reactive gas mixture (total pressure of $2 \mathrm{~Pa}$ ). (a) Transmittance and reflectance spectra. (b) Tauc's plots of $(\alpha h v)^{2}$ vs. $(h v)$. Inset shows the variation in $E_{\mathrm{g}}$ vs. $T_{\mathrm{s}}$. 


\subsection{Electrical Properties}

The electrical properties of the optimized RF sputtered $\mathrm{CuO}$ films deposited at $350{ }^{\circ} \mathrm{C}$ were studied using the four-point probe technique in the temperature range $25-100{ }^{\circ} \mathrm{C}$. Measurements give a room-temperature conductivity $(\sigma)$ of $4.0 \times 10^{-1} \mathrm{~S} \mathrm{~cm}^{-1}$. Figure 7 shows that the conductivity is thermally activated; the plot $\ln (\sigma)$ vs. 1000/T follows a linear behavior, from which the activation energy $E_{\mathrm{a}}$ is obtained using the Arrhenius law:

$$
\sigma=n e \mu=\sigma_{0} \exp \left(\frac{E_{a}}{k_{B} T}\right)
$$

where $n$ is the carrier (hole) concentration, $e$ is the elementary charge, $\mu$ is the mobility, $\sigma_{0}$ is a pre-exponential factor, $k_{B}$ is the Boltzmann constant and $T$ is the absolute temperature. The activation energy $( \pm 0.02 \mathrm{eV})$ of $\mathrm{CuO}$ films deposited at $350^{\circ} \mathrm{C}$ is $0.23 \mathrm{eV}$. The p-type semiconducting character of RF sputtered films is confirmed by hot probe measurement, which is attributed to copper deficiency. These results are consistent with those of the literature $[33,36,41]$.

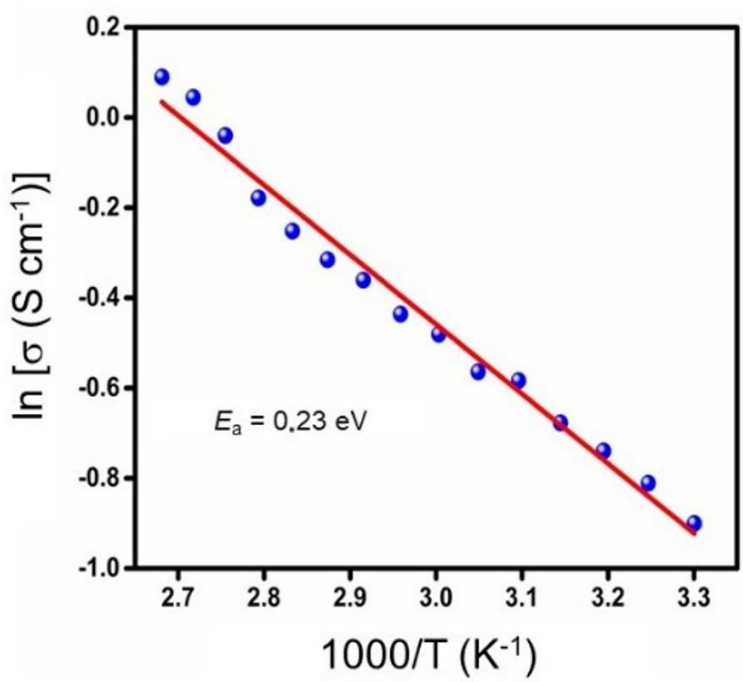

Figure 7. Arrhenius plot of the electrical conductivity of RF sputtered $\mathrm{CuO}$ film deposited at $T_{\mathrm{S}}=350{ }^{\circ} \mathrm{C}$ in the $\mathrm{O}_{2} / \mathrm{Ar}(1: 7)$ reactive gas mixture (total pressure of $2 \mathrm{~Pa}$ ).

The above investigations demonstrate that the fundamental thermodynamic parameter $\left(T_{\mathrm{s}}\right)$ effectively governs the growth and microstructure of sputtered $\mathrm{CuO}$ films. The films deposited at the optimized substrate temperature of $350{ }^{\circ} \mathrm{C}$ were found to be single phase with the monoclinic structure ( $\mathrm{C} 2 / \mathrm{c}$ space group), with an estimated elementary volume of $83.015 \AA^{3}$, which is only $0.2 \%$ less than the value for the bulk crystal, indicating the formation of rather dense films. The Raman and optical studies confirmed the existence of the $\mathrm{CuO}$ phase. The crystallographic structure with good integrity between the crystallites was observed through SEM and AFM studies with an estimated average crystallite size and surface roughness of $134 \pm 2$ and $45 \pm 2 \mathrm{~nm}$, respectively, providing a high specific surface area of $10.5 \mathrm{~m}^{2} \mathrm{~g}^{-1}$. Hence, the $\mathrm{CuO}$ film electrodes prepared at $350{ }^{\circ} \mathrm{C}$ were subjected to electrochemical studies to demonstrate their applicability towards micro-supercapacitors.

\subsection{Electrochemical Properties}

The electrochemical properties of the RF sputtered $\mathrm{CuO}$ film prepared at $T_{\mathrm{S}}=350{ }^{\circ} \mathrm{C}$, i.e., cyclic voltammetry and galvanostatic charge-discharge profiles, were carried out using a conventional three-electrode cell with $1 \mathrm{~mol} \mathrm{~L}^{-1}$ saturated phosphate-buffered saline (PBS) aqueous solution ( $\mathrm{pH}=7.2$ ) as the electrolyte. Results are presented in Figure 8. The typical CV curves were recorded in the potential window of -0.8 to $+0.0 \mathrm{~V}$ with respect to $\mathrm{Ag} / \mathrm{AgCl}$ as the reference electrode at different scan rates in the range $1-100 \mathrm{mV} \mathrm{s}^{-1}$ 
(Figure 8a). The CV profiles show one set of well-defined and intense cathodic and anodic peaks assigned to the faradaic redox reaction of the $\mathrm{Cu}(\mathrm{I}) / \mathrm{Cu}(\mathrm{II})$ transition. In contrast with the electrochemical double-layer (EDL) capacitors, which display rectangular shaped and nearly symmetric $\mathrm{CV}$ curves, the electrochemical response of $\mathrm{CuO}$ films evidences a pseudocapacitive behavior. It can be observed that, with increasing the scan rate, the CV profiles remained almost unchanged. The corresponding increase in the peak current $\left(i_{\mathrm{p}}\right)$ and integral area under the $\mathrm{CV}$ curves confirms the excellent electrochemical kinetics and the reversibility of the film electrodes. At the scan rate of $1 \mathrm{mV} \mathrm{s}^{-1}$, the $\mathrm{CV}$ profile of $\mathrm{CuO}$ films exhibits an anodic peak at $-0.27 \mathrm{~V}$, which originates from the oxidation of $\mathrm{Cu}^{+}$to $\mathrm{Cu}^{2+}$, and a cathodic peak located at $-0.02 \mathrm{~V}$, which is assigned to the reduction of $\mathrm{Cu}^{2+}$ to $\mathrm{Cu}^{+}$[67]. With increasing scan rates, the cathodic and anodic peaks shift to lower and higher potentials, respectively, which is due to an increase in polarization [68]. The phase pure (111)-orientated $\mathrm{CuO}$ films with good crystallinity provide easy transportation of redox species and enrich the overall electrochemical performance of the film electrodes.
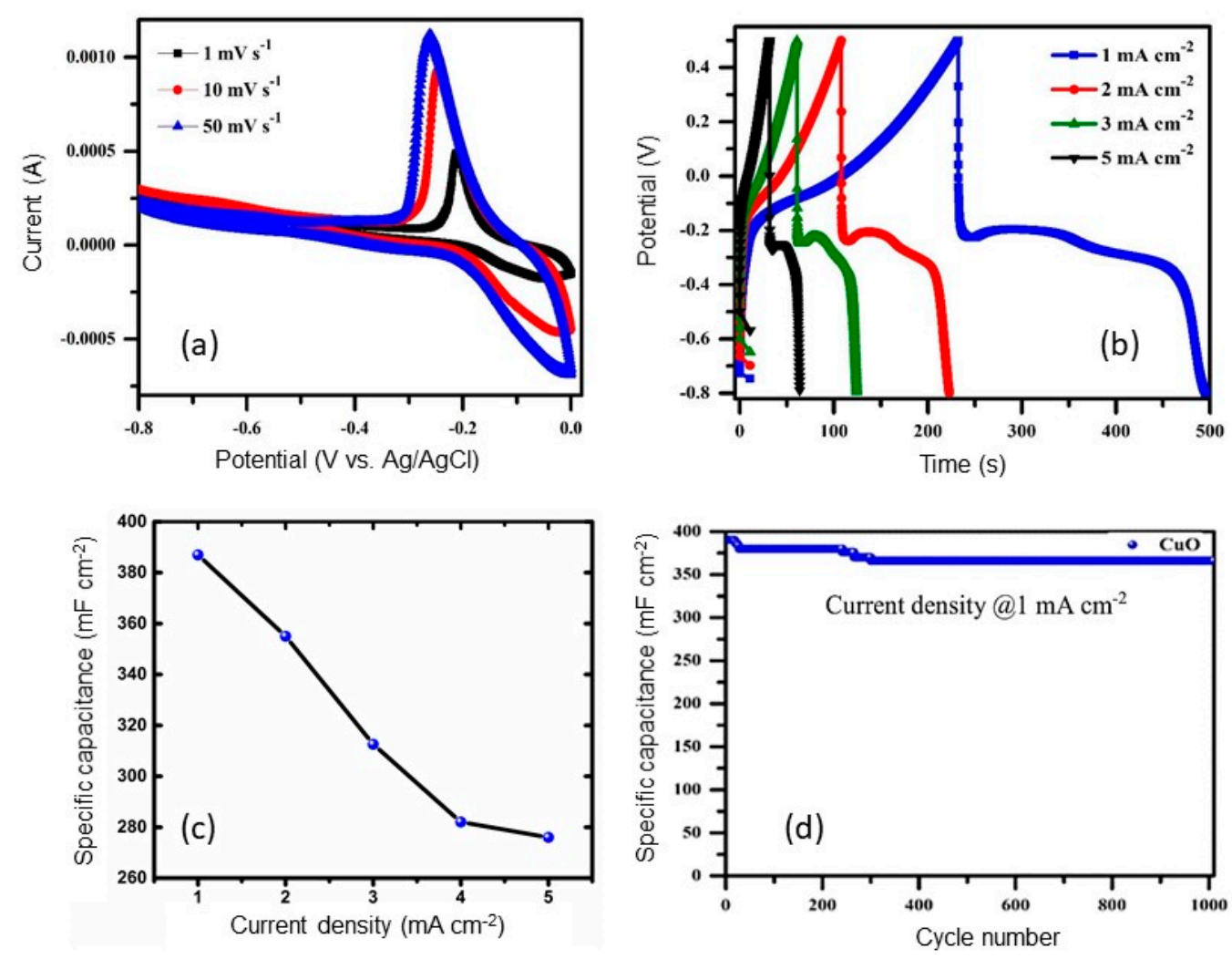

Figure 8. Electrochemical properties of the RF sputtered $\mathrm{CuO}$ film conducted in a three-electrode cell with $1 \mathrm{~mol} \mathrm{~L}^{-1}$ phosphate-buffered saline aqueous electrolyte. (a) Cyclic voltammograms recorded at various scan rates. (b) Galvanostatic charge-discharge profiles at different current densities. (c) Specific capacitance as a function of discharge current densities. (d) Cycling stability at current density of $1 \mathrm{~mA} \mathrm{~cm}^{-2}$.

The fast Li-ion kinetics at the surface of the electrode is a result of the high surface area. In order to distinguish the relative charge storage contribution from diffusion-controlled and surface effects, a series of CV tests were conducted at a scan rate of $1-100 \mathrm{mV} \mathrm{s}^{-1}$ in the potential window of $0.01-0.8 \mathrm{~V}$. The general approach for the analysis of the scan rate can be described by a power law [69]:

$$
i_{\mathrm{p}}=k v^{\mathrm{b}},
$$

where $i_{\mathrm{p}}$ is the current, $v$ is the potential scan rate $\left(\mathrm{V} \mathrm{s}^{-1}\right)$ and $k$ and $b$ are arbitrary coefficients. The coefficient $b$ can vary from 0.5 to 1.0 , with $b=0.5$ being characteristic of a 
diffusion-limited process (charge storage via ion insertion) and $b=1.0$ being characteristic of a capacitance process (charge storage via surface capacitance effects). From the slope of $\log i_{\mathrm{p}}$ vs. $\log v$, the calculated $b$ value for the $\mathrm{CuO}$ film is 0.68 , indicating that the current response is pseudocapacitive as the result of a combination of capacitive and insertion processes.

The GCD curves of the RF sputtered $\mathrm{CuO}$ films recorded at different current densities from 1 to $5 \mathrm{~mA} \mathrm{~cm}^{-2}$ in 1 mole PBS solution $(\mathrm{pH}=7.2)$ are shown in Figure 8b. These nonlinear-shaped profiles confirm the pseudocapacitive behavior of the $\mathrm{CuO}$ electrode in contrast with EDL capacitors which present nearly linear discharge slopes. The potential vs. time discharge curve is composed of three regions: first, a large drop in voltage due to the internal resistance, followed by a flat region at a potential of $-0.2 \mathrm{~V}$ corresponding to a double-layer capacitance behavior and, finally, a slopy potential related to the charge transfer reaction. These features corroborate the $\mathrm{CV}$ profile. The specific capacitance $\left(C_{\mathrm{s}}\right)$ of the RF sputtered $\mathrm{CuO}$ film electrodes was calculated using the formula [70]:

$$
C_{\mathrm{s}}=\frac{I}{\left(\frac{\Delta V}{\Delta t}\right) A},
$$

where $I$ is the current, $\Delta V$ is the potential change during the discharge process, $\Delta t$ is the discharge time and $A$ is the active area of the electrode. Figure $8 \mathrm{c}$ shows the specific capacitance of the RF sputtered $\mathrm{CuO}$ film electrode as a function of the current density. Specific capacitances of $387,355,347,282$ and $276 \mathrm{mF} \mathrm{cm}^{-2}$ are delivered at current densities of $1,2,3,5$ and $10 \mathrm{~mA} \mathrm{~cm}^{-2}$, respectively. It can be noticed that the specific capacitance can be decreased gradually with increasing current densities because of the large voltage change and limited diffusion of the active ion at the surface of the film during the fast charging/discharging reaction. Moreover, less redox sites at the surface can react with the electrolyte when the current density increases [70].

The cycling stability of $\mathrm{CuO}$ film electrodes investigated at a current density of $1 \mathrm{~mA}$ $\mathrm{cm}^{-2}$ is shown in Figure 8d. A slight decrease in the specific capacitance during early cycles is due to the cell formation, i.e., a dissolution of the material and irreversible reaction of the electrode which occurred at the initial stage. After 300 cycles, the specific capacitance value remains constant, indicating the excellent stabilization of the $\mathrm{CuO}$ film electrode. The $\mathrm{RF}$ sputtered $\mathrm{CuO}$ film electrode delivers an initial specific capacitance of $387 \mathrm{mF} \mathrm{cm}{ }^{-2}$ at $1 \mathrm{~mA} \mathrm{~cm}{ }^{-2}$ current density (corresponding to $\sim 1.5 \mathrm{~A} \mathrm{~g}^{-1}$ ) and $95 \%$ capacitance retention (i.e., $367 \mathrm{mF} \mathrm{cm}^{-2}$ ) even after 1000 cycles. These results are comparatively higher than the values in the literature (see next section). The high capacitance and excellent cycling stability can be attributed to three reasons: (1) the open nanograins shorten the distance of ion diffusion and improve the ionic and electronic conductivity, (2) the rough surface structure of the electrode not only provides a large surface area and mechanical strength, but also facilitates the 3D storage of charges and (3) the thermodynamically stable (111) planes can provide high conductivity and promote a large storage capacity.

The electrochemical impedance spectroscopy (EIS) measurements were carried out in the frequency range from $0.01 \mathrm{~Hz}$ to $1 \mathrm{MHz}$ in PBS solution. The Nyquist plot $Z^{\prime \prime}(\omega)$ vs. $Z^{\prime}(\omega)$ of the $\mathrm{CuO}$ film deposited at $350^{\circ} \mathrm{C}$ is shown in Figure 9, together with the equivalent circuit used to fit the data. The Nyquist plot is composed of a depressed semicircle at the high- to middle-frequency region and a steeper line at the low-frequency range. The depressed semicircle corresponds to the charge transfer resistance $\left(R_{\mathrm{ct}}\right)$ caused by faradaic reactions (i.e., $\mathrm{Cu}^{2+} / \mathrm{Cu}^{+}$redox couple). The steeper line evidences the capacitive nature of the electrode (it should be a vertical line for an ideal capacitor). The ohmic resistance $\left(R_{S}\right)$ of the $\mathrm{CuO}$ electrode is calculated from the intercept of the real axis at the high-frequency range. The values of $R_{\mathrm{ct}}$ and $R_{\mathrm{S}}$ are found to be $\sim 10.8$ and $\sim 1.4 \Omega$, respectively. These low values support the claim of higher electrical conductivity (low $R_{\mathrm{ct}}$ value) and a larger electro-active surface area for the RF sputtered $\mathrm{CuO}$ electrode. The efficient ion transport pathways are supplied by the film architecture, providing a high surface area and thermodynamically stable (1111)-oriented crystal planes. 


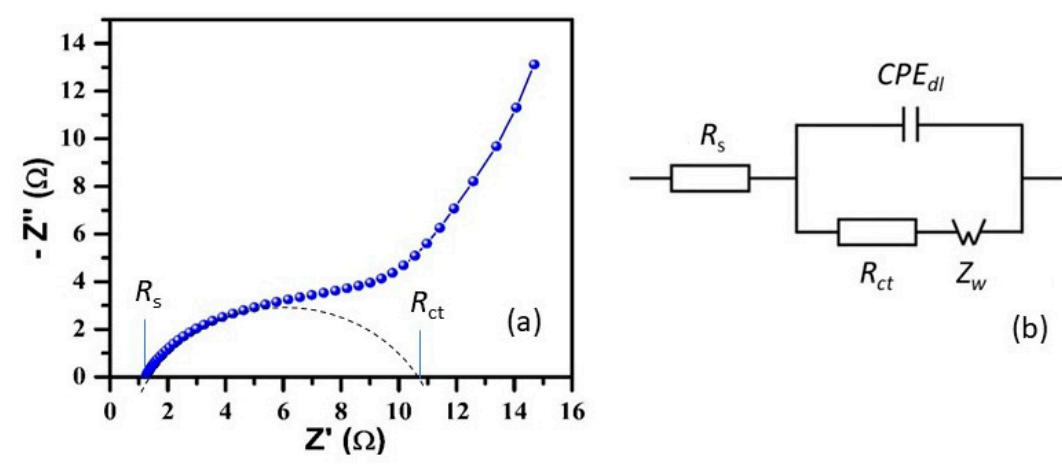

Figure 9. (a) Nyquist plot of the RF sputtered $\mathrm{CuO}$ electrode deposited at $T_{\mathrm{S}}=350{ }^{\circ} \mathrm{C}$. (b) Equivalent circuit.

\section{Discussion}

In this work, we have shown the influence of the substrate temperature on the morphology of RF sputtered copper oxide(II) films. The best crystallinity was simply formed at $350{ }^{\circ} \mathrm{C}$ under an $\mathrm{O}_{2} /$ Ar reactive atmosphere with a ratio of $1: 7$ and an oxygen partial pressure of $p\left(\mathrm{O}_{2}\right) \approx 0.9 \mathrm{~Pa}$ without post-annealing treatment. The deposition rate of the tenorite phase was as low as $\sim 1.2 \mu \mathrm{m} \mathrm{h}^{-1}$ due to the easy oxidation of the $\mathrm{Cu}$ target through the oxygen flow of $0.1 \mathrm{sccm}$. Such a growth behavior was also observed for $\mathrm{CuO}$ films prepared by pulsed-laser deposition, showing the appearance of a granular texture at $T_{\mathrm{S}}=400{ }^{\circ} \mathrm{C}$ [55]. However, there is some discrepancies relative to the sputtering growth conditions with literature data. As pointed out by Parretta et al. [71], the sputtering deposition rate, Qs, is strongly dependent on the $\mathrm{O}_{2}$ concentration in the gas mixture and weakly affected by the deposition temperature, and Qs becomes almost constant for $p\left(\mathrm{O}_{2}\right)>0.2 \mathrm{~Pa}$ at a low deposition temperature $\left(25^{\circ} \mathrm{C}\right)$. Cho et al. [37] reported that $\mathrm{CuO}$ films (50 nm crystallite size) prepared by reactive RF magnetron sputtering show a monoclinic structure with the main $\mathrm{CuO}$ (111) orientation irrespective of the substrate temperature but also stated that the highest figure of merit occurs at $T_{\mathrm{s}}=300{ }^{\circ} \mathrm{C}$. In their recent work, Asl and Rozati [72] successfully demonstrated the influence of the substrate temperature (in the range $450-550{ }^{\circ} \mathrm{C}$ ) on fundamental properties of $\mathrm{CuO}$ films prepared by spray pyrolysis.

It appears that the pure $\mathrm{CuO}$ monoclinic phase is stable in the substrate temperature range $300-400{ }^{\circ} \mathrm{C}$, while the film grown at $T_{\mathrm{s}}<250{ }^{\circ} \mathrm{C}$ is poorly crystallized and displays a mixture of cubic $\mathrm{CuO}$ and $\mathrm{Cu}_{2} \mathrm{O}$. When heated at ca. $300^{\circ} \mathrm{C}$ in an oxygen-rich environment, the conversion of $\mathrm{Cu}_{2} \mathrm{O}$ to $\mathrm{CuO}$ is observed [33]. During subsequent heating up to $450{ }^{\circ} \mathrm{C}$, the monoclinic $\mathrm{CuO}$ phase is maintained without alteration [20]. For $T_{\mathrm{s}}>450{ }^{\circ} \mathrm{C}$, impurity phases such as $\mathrm{Cu}_{2} \mathrm{O}$ and $\mathrm{Cu}_{4} \mathrm{O}_{3}$ are mixed with monoclinic $\mathrm{CuO}$. The results are in good agreement with those of Pecquenard et al. [41], who prepared columnar $\mathrm{CuO}$ films with the monoclinic structure at $T_{\mathrm{s}}=350{ }^{\circ} \mathrm{C}$. Ghosh and coworkers [73] stated that $\mathrm{Cu}_{2} \mathrm{O}$ is the prominent phase at the substrate temperature in the range $30 \leq T_{\mathrm{s}} \leq 150{ }^{\circ} \mathrm{C}$, whereas the $\mathrm{CuO}$ phase is obtained at a $T_{\mathrm{s}}$ of $300^{\circ} \mathrm{C}$. Surprisingly, Al-Ghamdi et al. [74] claimed to prepare crystalline $\mathrm{CuO}$ films at $T_{\mathrm{s}}=25^{\circ} \mathrm{C}$ with the tenorite phase but did not specify the existence of oxygen in the sputtering process.

Even though $\mathrm{CuO}$ films have been intensively studied, the results reported in the different works differ due to the different experimental conditions, i.e., sputtering power, $\mathrm{O}_{2} / \mathrm{Ar}$ ratio and $p\left(\mathrm{O}_{2}\right)$. Several authors claim different features regarding the phase composition of the reactively sputtered films. In 2013, Cho et al. [37] prepared a variety of $\mathrm{CuO}$ films at different $T_{\mathrm{s}}$ and showed the best crystallized films at $T_{\mathrm{s}}=300^{\circ} \mathrm{C}$. Du et al. [54] reported a poor crystallization of $\mathrm{CuO}$ films deposited at $T_{\mathrm{S}}<300^{\circ} \mathrm{C}$ and the growth of $\mathrm{CuO}$ with a (111)-preferential orientation up to a $T_{\mathrm{s}}$ of $600{ }^{\circ} \mathrm{C}$. It is believed that, at $T_{\mathrm{s}}=350{ }^{\circ} \mathrm{C}$, the ad-atoms reaching the surface of the substrate initiate the nucleation due to a collision process, which supports the formation of islands in order to grow a film with a larger grain size. Here, the highly structured $\mathrm{CuO}$ film appears at a high sputtering power of $250 \mathrm{~W}$, which generates highly energized Ar ions during the deposition process. Such 
features have also been suggested by Chan and Teo for the deposition of copper films by DC magnetron sputtering [75]. In terms of a high surface area, our results (surface roughness of $45 \mathrm{~nm}$ ) are superior to previous reports. Poorly crystallized $\mathrm{CuO}$ oxide films prepared by dip coating displayed (111)-oriented grains with the size lying between 30 and $80 \mathrm{~nm}$ and a surface roughness of $\sim 19 \mathrm{~nm}$ [76]. The RF sputtered CuO films deposited on glass slides at room temperature are almost amorphous (cubic phase) with a grain size of $11 \mathrm{~nm}$ and an average surface roughness of $0.3 \mathrm{~nm}$ [77]. CuO films prepared by pulsed-laser deposition on a sapphire substrate maintained at $400{ }^{\circ} \mathrm{C}$ are composed of grains $>100 \mathrm{~nm}$ in size and a low surface roughness of $\sim 3 \mathrm{~nm}$ [78].

Results of the conductivity measurements $\left(\sigma=0.4 \mathrm{~S} \mathrm{~cm}^{-1}, E_{\mathrm{a}}=0.23 \mathrm{eV}\right)$ are consistent with most of the literature data [33,36,41]. As suggested by first principles calculation [79], the present experimental hot probe test evidenced the p-type semiconducting character of $\mathrm{CuO}$ films; thus, the $\mathrm{Cu}^{(\mathrm{I})}\left(\mathrm{d}^{10}\right)$-based oxide is naturally cation-deficient, and cation vacancies lead to delocalized conductive states near the top of the valence band. In our case, the large grains generated at $T_{\mathrm{s}}=350{ }^{\circ} \mathrm{C}$ reduce the grain boundaries. The high value of $\sigma$ is attributed to the minor role in the hole transport played by the grain boundary scattering. Cho et al. [37] found that the growth temperature critically modulates the bandgap and carrier concentration. For example, RF sputtered $\mathrm{CuO}$ films deposited on glass slides exhibit an increase by three orders of magnitude in the hole concentration ranging from $1.6 \times 10^{14}$ to $8.5 \times 10^{17} \mathrm{~cm}^{-3}$. CuO films obtained by oxidation of $\mathrm{Cu}_{2} \mathrm{O}$ at $400{ }^{\circ} \mathrm{C}$ have shown a high conductivity of $4.0 \times 10^{-1} \mathrm{~S} \mathrm{~cm}^{-1}$ [32]. Pierson et al. [36] reported a resistivity of $100 \Omega \mathrm{cm}$ for a $\mathrm{CuO}$ film deposited by reactive magnetron sputtering, which exhibits a bandgap of $E_{\mathrm{g}}=1.71 \mathrm{eV}$. Prabu et al. [80] showed that the conductivity of $\mathrm{CuO}$ films deposited by spray pyrolysis depends strongly on the deposition temperature. At $320^{\circ} \mathrm{C}$, the films display a conductivity of $2.16 \times 10^{-3} \mathrm{~S} \mathrm{~cm}^{-1}$, Hall mobility of $1 \mathrm{~cm}^{2} \mathrm{~V}^{-1} \mathrm{~s}^{-1}$ and hole concentration of $1.35 \times 10^{16} \mathrm{~cm}^{-3}$. Note that the small discrepancy is due to the difference in crystallinity and grain size. Pecquenard et al. [41] demonstrated that sputtered $\mathrm{CuO}$ films obtained with an oxygen concentration of $12 \%\left(6 \mathrm{sccm} \mathrm{O}_{2}\right.$ flow rate, total $\mathrm{Ar}+\mathrm{O}_{2}$ pressure of $0.5 \mathrm{~Pa}$ ) have a high electronic conductivity of $9.3 \times 10^{-3} \mathrm{~S} \cdot \mathrm{cm}^{-1}$ with an activation energy of $0.11 \mathrm{eV}$. When the oxygen flow rate decreases to $5 \mathrm{sccm}$, the conductivity is reduced to $3.9 \times 10^{-3} \mathrm{~S} \cdot \mathrm{cm}^{-1}$. Recently, Baturay et al. [81] established that $\mathrm{CuO}$ films prepared by spin coating on soda-lime glasses with subsequent annealing at $500{ }^{\circ} \mathrm{C}$ for $1 \mathrm{~h}$ exhibit a p-type conduction with a resistivity of $68.2 \Omega \mathrm{cm}$ and charge carrier density of $4.4 \times 10^{17} \mathrm{~cm}^{-3}$. Asl and Rozati [73] evidenced the influence of the deposition temperature on the electrical properties of $\mathrm{CuO}$ films prepared by spray pyrolysis in the range $450-550{ }^{\circ} \mathrm{C}$. The resistivity decreases from 7.94 to $1.68 \mathrm{k} \Omega \mathrm{cm}$, while the carrier concentration increases from $8.03 \times 10^{13}$ to $1.90 \times 10^{15} \mathrm{~cm}^{-3}$ when $T_{\mathrm{s}}$ varies from 450 to $550{ }^{\circ} \mathrm{C}$. This tendency was attributed to the reduction in the barrier height at the grain boundaries by virtue of a larger crystallite size. Table 3 summarizes the electrical characteristics of $\mathrm{CuO}$ films from the literature.

Table 3. Electrical characteristics of $\mathrm{CuO}$ films from the literature. (a) value measured at $100{ }^{\circ} \mathrm{C}$.

\begin{tabular}{|c|c|c|c|}
\hline Growth Conditions & $\begin{array}{c}\text { Conductivity } \\
\text { at } 25^{\circ} \mathrm{C} \\
\left(\mathrm{S} \mathrm{cm}{ }^{-1}\right)\end{array}$ & $\begin{array}{c}\text { Activation Energy } \\
(\mathrm{eV})\end{array}$ & Ref. \\
\hline sputtering; $T_{\mathrm{s}}=25^{\circ} \mathrm{C} ; p\left(\mathrm{O}_{2}\right)=2.5 \mathrm{~Pa}$; glass slide & $2.0 \times 10^{-3}$ & 0.14 & [82] \\
\hline sputtering; $T_{\mathrm{S}}=25^{\circ} \mathrm{C} ; p\left(\mathrm{O}_{2}\right)=0.08 \mathrm{~Pa}$; glass slide & $5.5 \times 10^{-3}$ & 0.22 & [71] \\
\hline spray deposition; $T_{\mathrm{S}}=350^{\circ} \mathrm{C}$; glass slide & $4.0 \times 10^{-6}$ & 0.97 & [29] \\
\hline spray pyrolysis; $T_{\mathrm{S}}=320^{\circ} \mathrm{C}$; glass slide & $2.1 \times 10^{-3}$ & 0.012 & [80] \\
\hline sputtering; $T_{\mathrm{s}}=25^{\circ} \mathrm{C} ; F\left(\mathrm{O}_{2}\right)=5 \mathrm{sccm} ;$ silicon & $3.9 \times 10^{-3(a)}$ & 0.25 & [41] \\
\hline sputtering; $T_{\mathrm{s}}=25^{\circ} \mathrm{C} ; F\left(\mathrm{O}_{2}\right)=5 \mathrm{sccm} ;$ silicon & $9.3 \times 10^{-3(a)}$ & 0.11 & [41] \\
\hline spray pyrolysis; $T_{\mathrm{s}}=475^{\circ} \mathrm{C}$; glass slide & $3.4 \times 10^{-4}$ & - & [83] \\
\hline spray pyrolysis; $T_{\mathrm{S}}=400^{\circ} \mathrm{C}$; glass slide & $1.8 \times 10^{-3}$ & 0.31 & [84] \\
\hline sputtering; $T_{\mathrm{S}}=350^{\circ} \mathrm{C} ; p\left(\mathrm{O}_{2}\right)=2 \mathrm{~Pa} ; \mathrm{Si}$ wafer & $4.0 \times 10^{-1}$ & 0.23 & this work \\
\hline
\end{tabular}


The average value of the bandgap $E_{\mathrm{g}}=1.65 \pm 0.01 \mathrm{eV}$ confirms the monoclinic $\mathrm{CuO}$ structure of the sputtered films and is in good agreement with values of the literature [56,85-89]. The shift in the absorption edge to the higher wavelength and the slight decrease in the bandgap with increasing substrate temperature increase, which are assigned to the enhanced crystallinity of $\mathrm{CuO}$ films along with the reduction in porosity [56]. Dolai et al. [89] prepared polycrystalline $\mathrm{CuO}$ films using $\mathrm{DC}$ magnetron sputtering in $\mathrm{Ar} / \mathrm{O}_{2}$ (60:40) plasma. The films deposited onto glass substrates maintained at $300 \leq T_{\mathrm{s}} \leq 400$ ${ }^{\circ} \mathrm{C}$ show optical bandgaps in the range $1.58-1.60 \mathrm{eV}$. In contrast, cupric oxide $(\mathrm{CuO})$ films deposited on Si substrates by the RF magnetron sputtering technique show a nano-pillar morphology with a root mean square surface roughness of $3.64 \mathrm{~nm}$ and an optical direct bandgap energy of $1.37 \mathrm{eV}$ [40].

Presently, electrochemical measurements have shown the remarkable supercapacitive properties of the RF sputtered $\mathrm{CuO}$ films fabricated at $T_{\mathrm{s}}=350{ }^{\circ} \mathrm{C}$ under a reactive atmosphere $\left(\mathrm{O}_{2} / \mathrm{Ar}\right.$ of 1:7) with a specific capacitance of $355 \mathrm{mF} \mathrm{cm}^{-2}$ at a current density of $2 \mathrm{~mA} \mathrm{~cm}^{-2}$. To compare our results with those of the literature, let us calculate the gravimetric capacitance. Considering that the as-sputtered $\mathrm{CuO}$ films $(1.53 \mu \mathrm{m}$ thick $)$ are as dense as the bulk material $\left(\sim 6.8 \mathrm{~cm}^{3} \mathrm{~g}^{-1}\right)$, the areal capacitance of $355 \mathrm{~F} \mathrm{~cm}^{-2}$ converts to the gravimetric capacitance of $375 \mathrm{~F} \mathrm{~g}^{-1}$. This performance is improved importantly with respect to our prior work [42], which demonstrates that the optimization of the substrate temperature is an important parameter, since it impacts the crystallinity and the strain field of $\mathrm{CuO}$. The obtained performance is superior to that obtained for a $\mathrm{CuO}$ film deposited by chemical bath deposition on a stainless-steel (SS) substrate, i.e., $79 \mathrm{mF} \mathrm{g}^{-1}$ at current densities of $2 \mathrm{~mA} \mathrm{~cm}^{-2}$ [90]. Similarly, a lower capacitance of $357 \mathrm{mF} \mathrm{cm}^{-2}$ at $0.5 \mathrm{~mA} \mathrm{~cm}^{-2}$ was reported by Purusottam-Reddy for RF sputtered $\mathrm{CuO}$ films deposited on stainless-steel and maintained at $T_{\mathrm{s}}=350^{\circ} \mathrm{C}$ under a reactive $\mathrm{O}_{2} / \mathrm{Ar}(1: 11)$ gas mixture [42]. Supercapacitive performances of other $\mathrm{CuO}$ films are summarized as follows. Kambale et al. [45] prepared $\mathrm{CuO}$ films by automatic spray pyrolysis via an aqueous solution of $\mathrm{Cu}\left(\mathrm{NO}_{3}\right)_{2} \cdot 3 \mathrm{H}_{2} \mathrm{O}$. The films deposited at $400{ }^{\circ} \mathrm{C}$ on stainless-steel substrates display a specific capacitance of $58.2 \mathrm{~F} \mathrm{~g}^{-1}$ in $1 \mathrm{~mol} \mathrm{~L}^{-1}$ of a $\mathrm{KOH}$ electrolyte. Waikar and collaborators [90] studied the supercapacitive performance of $\mathrm{CuO}$ films deposited onto stainless-steel substrates via a chemical method assisted by ammonia as a complexing agent. Pure $\mathrm{CuO}$ films obtained after removing hydroxide by annealing at $200^{\circ} \mathrm{C}$ for $2 \mathrm{~h}$ exhibit a mesoporous morphology with a crystallite size of $\sim 13 \mathrm{~nm}$ and a BET specific surface area of $\sim 40 \mathrm{~m}^{2} \mathrm{~g}^{-1}$. These electrodes achieved a specific capacitance of $576 \mathrm{~F} \mathrm{~g}^{-1}$ at a $5 \mathrm{mV} \mathrm{s}^{-1}$ scan rate. Dubal et al. [10] studied the cauliflower-like structures of $\mathrm{CuO}$ films, which exhibit a specific capacitance of $179 \mathrm{~F} \mathrm{~g} \mathrm{~g}^{-1}$ at a $100 \mathrm{mV} \mathrm{s}^{-1}$ scan rate in $1 \mathrm{~mol} \mathrm{~L}^{-1}$ of a $\mathrm{Na}_{2} \mathrm{SO}_{4}$ aqueous electrolyte having $81 \%$ stability over 2000 cycles. Senthilkumar et al. [91] prepared $\mathrm{CuO}$ films by a chemical method on Ni foam and found $536 \mathrm{~F} \mathrm{~g}^{-1}$ specific capacitance in $6 \mathrm{~mol} \mathrm{~L}^{-1}$ of a $\mathrm{KOH}$ electrolyte with a $29.4 \mathrm{Wh} \mathrm{kg}^{-1}$ energy density, at a current density of $2 \mathrm{~A} \mathrm{~g} \mathrm{~g}^{-1}$, which corresponds to approximately $1.6 \mathrm{mV} \mathrm{s}^{-1}$. $\mathrm{Xu}$ et al. used a reflux method to prepare $\mathrm{CuO}$, but only the catalytic performance was investigated [92]. Such a reflux deposition approach to synthesize $\mathrm{CuO}$ nanosheets with supercapacitive performance was first proposed by Bhise et al. [93]. The nanosheets demonstrated $180 \mathrm{~F} \mathrm{~g}^{-1}$ specific capacitance at $10 \mathrm{mV}$ $\mathrm{s}^{-1}$ with $87 \%$ stability after 2000 cycles. More recently, Shelke et al. [43] also used the reflux approach to investigate the supercapacitor performance, but the film was insulating. In absence of structural analysis such as Raman spectroscopy or XPS, the composition of the film remains unknown, but the insulating property suggests that the material was not well-crystallized $\mathrm{CuO}$. The nanoflower-like structure of $\mathrm{CuO}$ films synthesized by Shinde et al. [46] on flexible $\mathrm{Cu}$ foil indicated the supercapacitor performance of a $\mathrm{CuO}$ electrode with $498 \mathrm{~F} \mathrm{~g}^{-1}$ specific capacitance and a $26 \mathrm{Wh} \mathrm{kg}^{-1}$ energy density at $5 \mathrm{mV} \mathrm{s}^{-1}$ in $1 \mathrm{~mol} \mathrm{~L}^{-1}$ of a $\mathrm{KOH}$ electrolyte. Dubal et al. [47] developed a $\mathrm{CuO}$ film through a chemical bath deposition process using $1 \mathrm{wt} . \%$ non-ionic surfactant Triton X-100 and polyvinyl alcohol. The porous and well-defined nanostructure displays a uniform size and highly $(\sim 10-20 \mathrm{~nm})$ nanosheet-constructed clusters, which achieved the maximum specific ca- 
pacitance of $396 \mathrm{~F} \mathrm{~g}^{-1}$ at $5 \mathrm{mV} \mathrm{s}^{-1}$. The same group also reported a capacitance of $411 \mathrm{~F}$ $\mathrm{g}^{-1}$ at $5 \mathrm{mV} \mathrm{s}^{-1}$ for a sample prepared by chemical deposition at the same scan rate [48]. Sayson [44] evaluated the supercapacitive properties of spray-deposited $\mathrm{CuO}$ films annealed at $400{ }^{\circ} \mathrm{C}$. In an aqueous electrolyte $\left(1 \mathrm{~mol} \mathrm{~L}^{-1} \mathrm{Na}_{2} \mathrm{SO}_{4}\right)$, the films exhibited a capacitance of $87 \mathrm{~F} \mathrm{~g}^{-1}$ at a scan rate of $10 \mathrm{mV} \mathrm{s}^{-1}$ and a retention of $84.7 \%$ after $1000 \mathrm{cy}$ cles. Patil et al. [32] reported a maximum specific capacitance of $184 \mathrm{~F} \mathrm{~g}^{-1}$ at the scan rate of $50 \mathrm{mV} \mathrm{s}^{-1}$ and $83 \%$ capacitive retention after 5000 cycles in $1 \mathrm{~mol} \mathrm{~L}^{-1}$ of a $\mathrm{KOH}$ electrolyte for $\mathrm{CuO}$ films grown by the SILAR technique. More recently, Khatavkar and Sartale [49] reported the deposition of copper hydroxide by liquid-phase deposition on stainless-steel (SS) substrates with subsequent annealing at $300-500{ }^{\circ} \mathrm{C}$ to obtain $\mathrm{CuO}$ films. The supercapacitive performance of $\mathrm{CuO}$ films was evidenced by a specific capacitance of $552 \mathrm{~F} \mathrm{~g}^{-1}$ at a scan rate of $3 \mathrm{mV} \mathrm{s}^{-1}$, provided that the substrate was a mesh SS. This large capacitance is due to the fact that at this very slow scan rate, the full electrochemical reaction can be achieved. However, at the current density of $2 \mathrm{~mA} \mathrm{~cm}^{-2}$ of practical use and used in this work, the capacitance was $58 \mathrm{~F} \mathrm{~g}^{-1}$ only. For the same reason, it is not possible to compare our results with the supercapacitive performance for different $\mathrm{CuO}$ supercapacitors reviewed in [49] because the results concern tests performed only at low scan rates of $\leq 10 \mathrm{mV} \mathrm{s}^{-1}$, at which capacitance larger than $500 \mathrm{~F} \mathrm{~g}^{-1}$ is expected and observed in different works. A benchmarking can be conducted, however, for $\mathrm{CuO}$ films with supercapacitance performance reported in the literature at the same current density of $2 \mathrm{~mA} \mathrm{~cm}^{-2}$ as in the present work. The best results are reported in Table 4 . They include flower-like $\mathrm{CuO}$ standing on $\mathrm{Cu}(\mathrm{OH})_{2}$ nanowire arrays on a copper foil prepared by a liquid-solid reaction, which exhibited a capacity of $278 \mathrm{~F} \mathrm{~g}^{-1}$ [94]. CuO nanoparticles anchored on $\mathrm{N}$-doped reduced graphene oxide prepared by refluxing in ammonia solution demonstrated a capacitance of $225 \mathrm{~F} \mathrm{~g}^{-1}$ at this same current density [95]. The larger specific capacitance observed in the present work is thus also a demonstration of the efficiency of the RF sputtering process to synthesize $\mathrm{CuO}$ for supercapacitive performance. We also report in Table 4 the electrolyte used for the measurements, since the capacitance also depends on this parameter. However, despite the fact that the choice of the electrolyte differs between the different works, Table 4 gives evidence that the reactive RF sputtering process gives the best supercapacitance performance.

Table 4. Comparison of the supercapacitive properties of $\mathrm{CuO}$ films tested at $2 \mathrm{~mA} \mathrm{~cm}{ }^{-2}$ current density. PBS = phosphate-buffered aqueous solution.

\begin{tabular}{cccc}
\hline Preparation Method & $\begin{array}{c}\text { Specific Capacitance } \\
\left(\mathbf{F ~ g}^{-\mathbf{1}}\right)\end{array}$ & Electrolyte & Ref. \\
\hline Liquid-solid reaction & 278 & $\mathrm{NaOH}$ & {$[94]$} \\
Reflux process & 225 & $\mathrm{KOH}$ & {$[95]$} \\
Chemical deposition & 79 & $\mathrm{Na}_{2} \mathrm{SO}_{4}$ & {$[90]$} \\
Surface oxidation of Cu & 190 & $\mathrm{KOH}$ & {$[50]$} \\
Reactive RF sputtering & 375 & $\mathrm{PBS}$ & this work \\
\hline
\end{tabular}

The maximum specific capacitance $\left(387 \mathrm{mF} \mathrm{cm}^{-2}\right)$ for the $\mathrm{CuO}$ thin films prepared at $350^{\circ} \mathrm{C}$ can be explained by understanding three important factors, i.e., the grain morphology, the surface constitution and the electroconductivity. As mentioned, in the case of $\mathrm{CuO}$ films, the grains are well-crystallized with an oval-elongated shape and the main (111) orientation irrespective of the substrate temperature, which result in a well-ordered electroactive framework. The surface chemistry of films plays a decisive role in determining the electrode-electrolyte kinetics, especially in the case of aqueous electrolytes [96]. Tobari et al. [96] showed experimentally and theoretically that the electrical capacitance (C) of film capacitors with realistic interface roughness is significantly larger than the value of flat and smooth electrodes of surface $A\left(C>\varepsilon_{\mathrm{o}} \varepsilon_{\mathrm{r}} A / h_{\mathrm{o}}\right)$. As mentioned, in the case of $\mathrm{CuO}$ electrodes, the charge storage mechanism is pseudocapacitive, which is basically influenced by the surface state [97]. Thus, the increase in the CuO film's surface roughness results in a 
higher specific surface area $\left(S_{B E T}=10.5 \mathrm{~m}^{2} \mathrm{~g}^{-1}\right)$, which creates excess capacitance in the micro-supercapacitor film. Moreover, the electronic conductivity of $0.4 \mathrm{~S} \mathrm{~cm}^{-1}$, suitable for easy insertion/de-insertion of ions, mostly contributes to the excellent redox reactions of the pseudocapacitor. In conclusion, the rough surface and the well-structured oval-shaped grains with the main (111) orientation perhaps dictate the electrochemical properties of the active electrode material, thus providing a higher number of electrochemically active sites for the pseudocapacitive behavior of CuO-based micro-supercapacitors.

\section{Conclusions}

In the present work, $\mathrm{CuO}$ films prepared by the $\mathrm{RF}$ magnetron sputtering technique were investigated as pseudocapacitive binder-free electrodes for micro-supercapacitors. Optimized $\mathrm{CuO}$ films were deposited on a silicon substrate at various temperatures, keeping the RF power at $250 \mathrm{~W}$ and the $\mathrm{O}_{2}$ to Ar gas ratio at 1:7. The XRD studies of the film prepared at a $T_{\mathrm{S}}$ of $350{ }^{\circ} \mathrm{C}$ exhibit the predominant (111) orientation along with other (110), (200) and (131) reflection lines corresponding to a monoclinic structure of the $\mathrm{CuO}$ phase. The estimated average crystallite size is approximately $24 \mathrm{~nm}$. The SEM analysis displays a uniform distribution of grains with an average grain size of $140 \mathrm{~nm}$. The AFM analysis reveals that the surface of the film is composed of oval-shaped grains providing a high surface roughness of $45 \mathrm{~nm}$. The calculated optical bandgap of copper oxide films is $1.68 \pm 0.01 \mathrm{eV}$ with a room-temperature electrical p-type conductivity of $0.4 \mathrm{~S} \mathrm{~cm}^{-1}$. The $\mathrm{CuO}$ film deposited at $350{ }^{\circ} \mathrm{C}$ exhibits a discharge specific capacitance of $387 \mathrm{mF} \mathrm{cm}^{-2}\left(375 \mathrm{~F} \mathrm{~g}^{-1}\right)$ at a current density of $1 \mathrm{~mA} \mathrm{~cm}^{-2}$ with excellent cyclic retention of $95 \%$ even after 1000 cycles. The high capacitance and good cycle stability can be explained by the rough surface and the well-structured oval-shaped grains with the main (1111) orientation that make the present $\mathrm{CuO}$ film electrodes promising potential electrodes for the next generation of micro-supercapacitors.

Author Contributions: Conceptualization, O.M.H.; investigation, G.M., R.M., S.P.K. and A.L.-N.; writing —original draft preparation, M.D. and N.G.; writing—review and editing, C.M.J. and A.M. All authors have read and agreed to the published version of the manuscript.

Funding: This research received no external funding.

Institutional Review Board Statement: Not applicable.

Informed Consent Statement: "Not applicable" for studies not involving humans.

Data Availability Statement: Data is contained within the article.

Conflicts of Interest: The authors declare no conflict of interest.

\section{References}

1. Lethien, C.; Bideau, J.L.; Brousse, T. Challenges and prospects of 3D micro-supercapacitors for powering the internet of things. Energy Environ. Sci. 2019, 12, 96-115. [CrossRef]

2. Eustache, E.; Douard, C.; Demortiere, A.; De Andrade, V.; Brachet, M.; Le Bideau, J.; Brousse, T.; Lethien, C. High areal energy 3D-interdigitated micro-supercapacitors in aqueous and ionic liquid electrolytes. Adv. Mater. Technol. 2017, 2, 1700126. [CrossRef]

3. Ferris, A.; Garbarino, S.; Guay, D.; Pech, D. 3D $\mathrm{RuO}_{2}$ micro supercapacitors with remarkable areal energy. Adv. Mater. 2015, 27, 6625-6629. [CrossRef]

4. Kotz, R.; Carlen, M. Principles and Applications of Electrochemical Capacitors. Electrochim. Acta 2000, 45, 2483-2498. [CrossRef]

5. Zhang, L.L.; Zhou, R.; Zhao, X.S. Graphene-based materials as supercapacitor electrodes. J. Mater. Chem. 2010, 20, 5983-5992. [CrossRef]

6. Miller, J.R.; Simon, P. Materials science, electrochemical capacitors for energy management. Science 2008, 321, 651-652. [CrossRef] [PubMed]

7. Shi, F.; Li, L.; Wang, X.-L.; Gu, C.-D.; Tu, J.-P. Metal oxide/hydroxide based materials for supercapacitors. RSC Adv. 2014, 4, 41910-41921. [CrossRef]

8. Lokhande, C.D.; Dubal, D.P.; Joo, O.S. Metal oxide thin film based supercapacitors. Current Appl. Phys. 2011, 11, 255-270. [CrossRef]

9. Bahloul, A.; Nessark, B.; Briot, E.; Groult, H.; Mauger, A.; Zaghib, K.; Julien, C.M. Polypyrrole-covered $\mathrm{MnO}_{2}$ as electrode material for hydrid supercapacitor. J. Power Sources 2013, 240, 267-272. [CrossRef] 
10. Dubal, D.P.; Gund, G.S.; Lokhande, C.D.; Holze, R. CuO cauliflowers for supercapacitor application: Novel potentiodynamic deposition. Mater. Res. Bull. 2013, 48, 923-928. [CrossRef]

11. Shinde, S.K.; Yadav, H.M.; Ghogake, G.S.; Kadam, A.A.; Kumbhar, V.S.; Yang, J.; Hwang, K.; Jagadale, A.D.; Kumar, S.; Kim, D.Y. Using chemical bath deposition to create nanosheet-like $\mathrm{CuO}$ electrodes for supercapacitor applications. Colloids Surf. B Biointerfaces 2019, 181, 1004-1011. [CrossRef] [PubMed]

12. Zhang, Y.X.; Huang, M.; Li, F.; Wen, Z.Q. Controlled synthesis of hierarchical CuO nanostructures for electrochemical capacitor electrodes. Int. J. Electrochem. Sci. 2013, 8, 8645-8661.

13. Grondahl, L.O. The copper-cuprous-oxide rectifier and photoelectric cell. Rev. Mod. Phys. 1933, 5, 141-160. [CrossRef]

14. Constable, F.H. Electrical conductivity of copper oxide films showing interference colours. Nature 1935, 136, 517. [CrossRef]

15. Son, D.I.; You, C.H.; Kim, T.W. Structural, optical, and electronic properties of colloidal CuO nanoparticles formed by using a colloid-thermal synthesis process. Appl. Surf. Sci. 2009, 255, 8794-8797. [CrossRef]

16. Papadimitropoulos, G.; Vourdas, N.; Vamvakas, V.E.; Davazoglou, D. Optical and structural properties of copper oxide thin films grown by oxidation of metal layers. Thin Solid Films 2006, 515, 2428-2432. [CrossRef]

17. Sohn, J.; Song, S.-H.; Nam, D.-W.; Cho, I.-T.; Cho, E.-S.; Lee, J.-H.; Kwon, H.-I. Effects of vacuum annealing on the optical and electrical properties of p-type copper-oxide thin-film transistors. Semicond. Sci. Technol. 2013, 28, 015005. [CrossRef]

18. Hoa, N.D.; An-Sca, S.Y.; Dung, N.Q.; Quy, N.V.; Kim, D. Synthesis of p-type semiconducting cupric oxide thin films and their application to hydrogen detection. Sens. Actuator B 2010, 146, 239-244. [CrossRef]

19. Dahrul, M.; Alatas, H.; Izaman, X. Preparation and optical properties study of CuO thin film as applied solar cell on LAPAN-IPB satellite. Proc. Environ. Sci. 2016, 33, 661-667. [CrossRef]

20. Figueiredo, V.; Elangovan, E.; Gonçalves, G.; Barquinha, P.; Pereira, L.; Franco, N.; Alves, E.; Martins, R.; Fortunato, E. Effect of post-annealing on the properties of copper oxide thin films obtained from the oxidation of evaporated metallic copper. Appl. Surf. Sci. 2008, 254, 3949-3954. [CrossRef]

21. Zhou, Y.C.; Switzer, J.A. Galvanostatic electrodeposition and microstructure of copper(I) oxide film. Mater. Res. Innov. 1998, 2, 22-27. [CrossRef]

22. Sagu, J.S.; Nirmal-Peiris, T.A.; Wijayantha, U. Rapid and simple potentiostatic deposition of copper(II) oxide thin films. Electrochem. Commun. 2014, 42, 68-71. [CrossRef]

23. Faiz, H.; Siraj, K.; Khan, M.F.; Irshad, M.; Majeed, S.; Rafique, M.S.; Naseem, S. Microstructural and optical properties of dysprosium doped copper oxide thin films fabricated by pulsed laser deposition technique. J. Mater. Sci. Mater. Electron. 2016, 27, 8197-8205. [CrossRef]

24. Santra, K.; Sarkar, C.K.; Mukherjee, M.K.; Ghosh, B. Copper-oxide thin-films grown by plasma evaporation method. Thin Solid Films 1992, 213, 226-229. [CrossRef]

25. Ramgir, N.S.; Ganapathi, S.K.; Kaur, M.; Datta, N.; Muthe, K.P.; Aswal, D.K.; Gupta, S.K.; Yakhmi, J.V. Sub-ppm H 2 S sensing at room temperature using $\mathrm{CuO}$ thin films. Sens. Actuators B 2010, 151, 90-96. [CrossRef]

26. Lu, H.C.; Chu, C.L.; Lai, C.Y.; Wang, Y.H. Property variations of direct-current reactive magnetron sputtered copper oxide thin films deposited at different oxygen partial pressures. Thin Solid Films 2009, 517, 4408-4412. [CrossRef]

27. Sravanthi, V.; Srikanth, T.; Reddy, A.S.; Reddy, P.S.; Reddy, C.S. Electron beam evaporated copper oxide thin films. IOSR J. Eng. 2018, 8, 82-87.

28. Muthe, K.P.; Vyas, J.C.; Narang, S.N.; Aswal, D.K.; Gupta, S.K.; Bhattacharya, D.; Pinto, R.; Kothiyal, G.P.; Sabharwal, S.C. A study of the $\mathrm{CuO}$ phase formation during thin film deposition by molecular beam epitaxy. Thin Solid Films 1998, 324, 37-43. [CrossRef]

29. Shabu, R.; Moses-Ezhil-Raj, A.; Sanjeeviraja, C.; Ravidhas, C. Assessment of CuO thin films for its suitablity as window absorbing layer in solar cell fabrications. Mater. Res. Bull. 2015, 68, 1-8. [CrossRef]

30. Morales, J.; Sanchez, L.; Martin, F.; Ramos-Barrado, J.R.; Sanchez, M. Nanostructured CuO thin film electrodes prepared by spray pyrolysis: A simple method for enhancing the electrochemical performance of $\mathrm{CuO}$ in lithium cells. Electrochim. Acta 2004, 49, 4589-4597. [CrossRef]

31. Baturay, S.; Tombak, A.; Kaya, D.; Ocak, Y.S.; Tokus, M.; Aydemir, M.; Kilicoglu, T. Modification of electrical and optical properties of $\mathrm{CuO}$ thin films by Ni doping. J. Sol-Gel Sci. Technol. 2016, 78, 422-429. [CrossRef]

32. Patil, A.S.; Patil, M.D.; Lohar, G.M.; Jadhav, S.T.; Fulari, V.J. Supercapacitive properties of CuO thin films using modified SILAR method. Ionics 2017, 23, 1259-1266. [CrossRef]

33. Nair, M.T.S.; Guerrero, L.; Arenas, O.L.; Nair, P.K. Chemically deposited copper oxide thin films: Structural, optical and electrical characteristics. Appl. Surf. Sci. 1999, 150, 143-151. [CrossRef]

34. Nicolau, Y.F. Solution deposition of thin solid compound films by a successive ionic-layer adsorption and reaction process. Appl. Surf. Sci. 1985, 22-23, 1061-1074. [CrossRef]

35. Julien, C.M.; Mauger, A.; Hussain, O.M. Sputtered $\mathrm{LiCoO}_{2}$ cathode materials for all-solid-state thin-film lithium microbatteries. Materials (Basel) 2019, 12, 2687. [CrossRef]

36. Pierson, J.F.; Thobor-Keck, A.; Billard, A. Cuprite, paramelaconite and tenorite films deposited by reactive magnetron sputtering. Appl. Surf. Sci. 2003, 210, 359-367. [CrossRef]

37. Cho, S. Optical and electrical properties of $\mathrm{CuO}$ thin films deposited at several growth temperatures by reactive RF magnetron sputtering. Met. Mater. Int. 2013, 19, 1327-1331. [CrossRef] 
38. Khalaf, M.K.; Said, S.N.; Abbas, A.J. Characterization of the copper oxide thin films deposited by DC sputtering technique. Eng. Tech. J. 2014, 32, 770-776.

39. Sanal, K.C.; Vikas, L.S.; Jayaraj, M.K. Room temperature deposited transparent p-channel CuO thin film transistors. Appl. Surf. Sci. 2014, 297, 153-157. [CrossRef]

40. Ooi, P.K.; Ching, C.G.; Ahmad, M.A.; Ng, S.S.; Abdullah, M.J.; Abu Hassan, H.; Hassan, Z. Characterizations of cupric oxide thin films on glass and silicon substrates by radio frequency magnetron sputtering. Sains Malays. 2014, 43, 617-621.

41. Pecquenard, B.; Le Cras, F.; Poinot, D.; Sicardy, O.; Manaud, J.P. Thorough characterization of sputtered CuO thin films used as conversion material electrodes for lithium batteries. ACS Appl. Mater. Interfaces 2014, 6, 3413-3420. [CrossRef]

42. Purusottam-Reddy, B.; Sivajee-Ganesh, K.; Jayanth-Babu, K.; Hussain, O.M.; Julien, C.M. Microstructure and supercapacitive properties of rf-sputtered copper oxide thin films: Influence of $\mathrm{O}_{2} / \mathrm{Ar}$ ratio. Ionics 2015, 21, 2319-2328. [CrossRef]

43. Shelke, A.R.; Lokhande, A.C.; Pujari, R.B.; Lokhande, C.D. Effect of N-complexing agents on the supercapacitive properties of reflux deposited $\mathrm{CuO}$ thin films. Int. J. Eng. Res. Technol. 2017, 10, 561-567.

44. Sayson, L.V.A.; Lopez, J.M.; Estacio, E.S.; Salvador, A.A.; Somintac, A.S. Nanostructured CuO thin film deposited on stainless steel using spray pyrolysis as supercapacitor electrode. Mater. Res. Express 2020, 6, 125551. [CrossRef]

45. Kambale, S.V.; Jadhav, A.L.; Kore, R.M.; Thakur, A.V.; Lokhande, B.J. Cyclic voltammetric study of CuO thin film electrodes prepared by automatic spray pyrolysis. Macromolecular Symp. 2019, 387, 1800213. [CrossRef]

46. Shinde, A.V.; Chodankar, N.R.; Lokhande, V.C.; Lokhande, A.C.; Ji, T.; Kim, J.H.; Lokhande, C.D. Highly energetic flexible all-solid-state asymmetric supercapacitor with $\mathrm{Fe}_{2} \mathrm{O}_{3}$ and $\mathrm{CuO}$ thin films. RSC Adv. 2016, 6, 58839-58843. [CrossRef]

47. Dubal, D.P.; Gund, G.S.; Holze, R.; Jadhav, H.S.; Lokhande, C.D.; Park, C.-J. Surfactant-assisted morphological tuning of hierarchical CuO thin films for electrochemical supercapacitors. Dalton Trans. 2013, 42, 6459-6467. [CrossRef]

48. Dubal, D.P.; Gund, G.S.; Holze, R.; Lokhande, C.D. Enhancement in supercapacitive properties of CuO thin films due to the surfactant mediated morphological modulation. J. Electroanal. Chem. 2014, 712, 40-46. [CrossRef]

49. Khatavkar, S.N.; Sartale, S.D. Superior supercapacitive performance of grass-like CuO thin films deposited by liquid phase deposition. New, J. Chem. 2020, 44, 6778-6790. [CrossRef]

50. Endut, Z.; Hamdi, M.; Basirun, W.J. Pseudocapacitive performance of vertical coper oxide nanoflakes. Thin Solid Films 2013, 528, 213-216. [CrossRef]

51. Purusottam-Reddy, B.; Sivajee-Ganesh, K.; Hussain, O.M. Growth, microstructure and supercapacitive performance of copper oxide thin films prepared by RF magnetron sputtering. Applied Phys. A 2016, 122, 128. [CrossRef]

52. Ali, M.; Gobinner, C.R.; Kekuda, D. Role of oxygen flow rate on the structural and optical properties of copper oxide thin films grown by reactive magnetron sputtering. Indian J. Phys. 2016, 90, 219-224. [CrossRef]

53. Dulmaa, A.; Vrielinck, H.; Khelifi, S.; Depla, D. Sputter deposition of copper oxide films. Appl. Surf. Sci. 2019, 492, 711-717. [CrossRef]

54. Du, Y.; Gao, X.; Zhang, X.; Meng, X. Characterization of the microstructure and the optical and electrical properties of the direct-current magnetron sputtered $\mathrm{CuO}$ films at different substrate temperatures. Phys. B Cond. Matter 2018, 546, 28-32. [CrossRef]

55. Muhammad, K.S.; Shazia, B.; Qazi, S.A.; Nazish, Y.; Sohail, A.J.; Mahreen, A.; Khaliq, M.; Ayesha, K. Effect of substrate temperature on the growth of copper oxide thin films deposited by pulsed laser deposition technique. Surf. Rev. Lett. 2018, 25, 1850053.

56. Xu, L.; Zhang, G.; Pei, S.; Wang, J. Investigation of optical bandgap variation and photoluminescence behavior in nanocrystalline CuO thin films. Optik 2018, 158, 382-390. [CrossRef]

57. Calos, N.J.; Forrester, J.S.; Schaffer, G.B. A crystallographic contribution to the mechanism mechanically induced solid state reaction. J. Solid State Chem. 1996, 122, 272-280. [CrossRef]

58. Langford, J.I.; Wilson, A.J.C. Scherrer after sixty years: A survey and some new results in the determination of crystallite size. J. Appl. Cryst. 1978, 11, 102-113. [CrossRef]

59. Sander, T.; Reindl, C.T.; Giar, M.; Eifert, B.; Heinemann, M.; Heiliger, C.; Klar, P.J. Correlation of intrinsic point defects and the Raman modes of cuprous oxide. Phys. Rev. B Condens. Matter 2014, 90, 045203. [CrossRef]

60. Debbichi, L.; de Lucas, M.C.M.; Pierson, J.F.; Krüger, P. Vibrational properties of $\mathrm{CuO}$ and $\mathrm{Cu}_{4} \mathrm{O}_{3}$ from first-principles calculations, and Raman and infrared spectroscopy. J. Phys. Chem. C 2012, 116, 10232-10237. [CrossRef]

61. Hodson, M.E.; Lee, M.R.; Parsons, I. Origins of the surface roughness of unweathered alkali feldspar grains. Geochim. Cosmochim. Acta 1997, 61, 3885-3896. [CrossRef]

62. Ghodselhi, T.; Vesaghi, M.A.; Shafiekhani, A.; Baghizadeh, A.; Lameii, M. XPS study of the Cu@Cu ${ }_{2} \mathrm{O}$ core-shell nanoparticles. Appl. Surf. Sci. 2008, 255, 2730-2734. [CrossRef]

63. Li, Z.; Tong, K.; Shi, R.; Shen, Y.; Zhang, Y.; Yao, Z.; Fan, J.; Thwaites, M.; Shao, G. Reactive plasma deposition of high quality single phase $\mathrm{CuO}$ thin films suitable for metal oxide solar cells. J. Alloys Compd. 2017, 695, 3116-3123. [CrossRef]

64. Sakai, Y.; Ninomiya, S.; Hiraoka, K. XPS depth analysis of CuO by electrospray droplet impact. Surf. Interface Anal. 2012, 43, 1605-1609. [CrossRef]

65. Rusu, D.I.; Rusu, G.G.; Luca, D. Structural characteristics and optical properties of thermally oxidized zinc films. Acta Phys. Polonica A 2011, 119, 850-856. [CrossRef]

66. Tauc, J. Optical Properties of Solids; Abeles, F., Ed.; North-Holland: Amsterdam, The Netherlands, 1972. 
67. Moosavifard, S.E.; El-Kady, M.F.; Rahmanifar, M.S.; Kaner, R.B.; Mousavi, M.F. Dedigning 3D highly ordered nanoporous CuO electrodes for high-performance asymmetric supercapacitors. ACS Appl. Mater. Interfaces 2015, 7, 4851-4860. [CrossRef] [PubMed]

68. Rajesh, J.A.; Min, B.K.; Kim, J.H.; Kang, S.H.; Kim, H.; Ahn, K.S. Facile hydrothermal synthesis and electrochemical supercapacitor performance of hierarchical coral-like $\mathrm{ZnCo}_{2} \mathrm{O}_{4}$ nanowires. J. Electroanal. Chem. 2017, 785, 48-57. [CrossRef]

69. Costentin, C.; Savéant, J.-M. Energy storage: Pseudocapacitance in prospect. Chem. Sci. 2019, 10, 5656-5666. [CrossRef]

70. Zhou, Y.; Jin, P.; Zhou, Y.; Zhu, Y. High-performance symmetric supercapacitors based on carbon nanotubes/graphite nanofiber nanocomposites. Sci. Rep. 2018, 8, 9005. [CrossRef]

71. Parretta, A.; Jayaraj, M.K.; Di Noceras, A.; Loreti, S.; Quercia, L.; Agati, A. Electrical and optical properties of copper oxide films prepared by reactive RF magnetron sputtering. Phys. Status Sol. 1996, 155, 399-404. [CrossRef]

72. Asl, H.Z.; Rozati, S.M. Spray deposited nanostructured $\mathrm{CuO}$ thin films: Influence of substrate temperature and annealing process. Mater. Res. 2018, 21, e20170754.

73. Ghosh, S.; Avasthi, D.K.; Shah, P.; Ganesan, V.; Gupta, A.; Sarangi, D.; Bhattacharya, R.; Assmann, W. Deposition of thin films of different oxides of copper by RF sputtering and their characterization. Vacuum 2000, 57, 377-385. [CrossRef]

74. Al-Ghamdi, A.A.; Khedr, M.H.; Ansari, M.S.; Hasan, P.M.Z.; Abdel-Wahab, M.S.; Farghali, A.A. RF sputtered CuO thin films: Structural, optical and photo-catalytic behavior. Phys. E 2016, 81, 83-90. [CrossRef]

75. Chan, K.-Y.; Teo, B.-S. Atomic force microscopy (AFM) and X-ray diffraction (XRD) investigations of copper thin films prepared by dc magnetron sputtering technique. Microelectron. J. 2006, 37, 1064-1071. [CrossRef]

76. Dhanasekaran, V.; Mahalingam, T.; Ganesan, V. SEM and AFM studies of dip-coated CuO nanofilms. Microsc. Res. Techn. 2013, 76, 58-65. [CrossRef]

77. Hammoodi, R.A.; Abbas, A.K.; Elttayef, A.K. Structural and optical properties of CuO thin films prepared via RF magnetron sputtering. Int. J. Appl. Innov. Eng. Manag. 2014, 3, 1-7.

78. Yousif, A.K.; Bader, B.A.; Mahdi, R.O. Morphological and optical properties of CuO/sapphire thin films prepared by pulsed laser deposition. Eng. Techn. J. 2014, 32, 892-898.

79. Raebiger, H.; Lany, S.; Zunger, A. Origins of the p-type nature and cation deficiency in $\mathrm{Cu}_{2} \mathrm{O}$ and related materials. Phys. Rev. $B$ 2007, 76, 045209. [CrossRef]

80. Prabu, R.D.; Valanarasu, S.; Ganesh, V.; Shkir, M.; Al Faify, S.; Kathalingam, A.; Srikumar, S.R.; Chandramohan, R. An effect of temperature on structural, optical, photoluminescence and electrical properties of copper oxide thin films deposited by nebulizer spray pyrolysis technique. Mater. Sci. Semicond. Proc. 2018, 74, 129-135. [CrossRef]

81. Baturay, S.; Tombak, A.; Batibay, D.; Ocak, Y.S. n-type conductivity of CuO thin films by metal doping. Appl. Surf. Sci. 2019, 477, 91-95. [CrossRef]

82. Drobny, V.F.; Pulfrey, D.L. Properties of reactively-sputtered copper oxide films. Thin Solid Films 1979, 61, 89-98. [CrossRef]

83. Asl, H.Z.; Rozati, S.M. Spray deposition of n-type cobalt-doped $\mathrm{CuO}$ thin films: Influence of cobalt doping on structural, morphological, electrical and optical properties. J. Electron. Mater. 2020, 49, 1534-1540. [CrossRef]

84. Singh, I.; Bedi, R.K. Studies and correlation among the structural, electrical and gas response properties of aerosol spray deposited self assembled nanocrystalline CuO. Appl. Surf. Sci. 2011, 257, 7592-7599. [CrossRef]

85. Abdel-Rafea, M.; Roushdy, N. Determination of the optical band gap for amorphous and nanocrystalline copper oxide thin films prepared by SILAR technique. J. Phys. D: Appl. Phys. 2008, 42, 015413. [CrossRef]

86. Johan, M.R.; Suan, M.S.M.; Hawari, N.L.; Ching, H.A. Annealing effects on the properties of copper oxide thin films prepared by chemical deposition. Int. J. Electrochem. Sci. 2011, 6, 6094-6104.

87. Akgul, F.A.; Akgul, G.; Yildirim, N.; Unalan, H.E.; Turan, R. Influence of thermal annealing on microstructural, morphological, optical properties and surface electronic structure of copper oxide thin films. Mater. Chem. Phys. 2014, 147, 987-995. [CrossRef]

88. Jandale, D.; Pawar, S.; Chougule, M.; Godse, P.; Patil, S.; Raut, B.; Sen, S.; Patil, V. Nanocrystalline CuO thin films for H2S monitoring: Microstructural and optoelectronic characterization. J. Sens. Technol. 2011, 1, 36-46.

89. Dolai, S.; Dey, R.; Das, S.; Hussain, S.; Bhar, R.; Pal, A.K. Cupric oxide (CuO) thin films prepared by reactive d.c. magnetron sputtering technique for photovoltaic application. J. Alloys Compd. 2017, 724, 456-464. [CrossRef]

90. Waikar, M.R.; Shaikh, A.A.; Sonkawade, R.G. The supercapacitive performance of woollen-like structure of CuO thin films prepared by the chemical method. Vacuum 2019, 161, 168-175. [CrossRef]

91. Senthilkumar, V.; Kim, Y.S.; Chandrasekaran, S.; Rajagopalan, B.; Kim, E.J.; Chung, J.S. Comparative supercapacitance performance of $\mathrm{CuO}$ nanostructures for energy storage device applications. RSC Adv. 2015, 5, 20545-20553. [CrossRef]

92. Xu, L.; Sithambaram, S.; Zhang, Y.; Chen, C.-H.; Jin, L.; Joesten, R.; Suib, S.L. Novel urchin-like CuO synthesized by a facile reflux method with efficient olefin epoxidation catalytic performance. Chem. Mater. 2009, 21, 1253-1259. [CrossRef]

93. Bhise, S.C.; Awale, D.V.; Vadiyar, M.M.; Patil, S.K.; Kokare, B.N.; Kolekar, S.S. Facile synthesis of CuO nanosheets as electrode for supercapacitor with long cyclic stability in novel methyl imidazole-based ionic liquid electrolyte. J. Solid State Electrochem. 2017, 21, 2585-2591. [CrossRef]

94. Hsu, Y.-K.; Chen, Y.-C.; Lin, Y.-G. Characteristics and electrochemical performances of lotus-like $\mathrm{CuO} / \mathrm{Cu}(\mathrm{OH})_{2}$ hybrid material electrodes. J. Electroanal. Chem. 2012, 673, 43-47. [CrossRef]

95. Li, Y.; Ye, K.; Cheng, K.; Cao, D.; Pan, Y.; Kong, S.; Zhang, X.; Wang, G. Anchoring CuO nanoparticles on nitrogen-doped reduced graphene oxide nanosheets as electrode material for supercapacitors. J. Electroanal. Chem. 2014, 727, 154-162. [CrossRef] 
96. Patake, V.D.; Lokhande, C.D.; Joo, O.S. Electrodeposited ruthenium oxide thin films for supercapacitor: Effect of surface treatments. Appl. Surf. Sci. 2009, 255, 4192-4196. [CrossRef]

97. Tobari, S.; Cherry, M.; Duijnstee, E.A.; Le Corre, V.M.; Qiu, L.; Hummelen, J.C.; Palasantzas, G.; Koster, L.J.A. Rough electrode creates excess capacitance in thin-film capacitors. ACS Appl. Mater. Interfaces 2017, 9, 27290-27297. 